\title{
Phylogeny of the Genera of Eubrianacinae and Descriptions of Additional Members of Eubrianax (Coleoptera: Psephenidae)
}

\author{
C.-F. LEE, P.-S. YANG, ${ }^{1}$ AND M. SATÔ ${ }^{2}$ \\ Department of Entomology, the Ohio Sate University, Museum of Biological Diversity, 1315 Kinnear Road, \\ Columbus, OH 43212
}

\begin{abstract}
Ann. Entomol. Soc. Am. 94(3): 347-362 (2001)
ABSTRACT A cladistic analysis of Eubriancinae was performed, using 21 characters from external morphology (eight from larvae, four from pupae, and nine from adults), and considering Psepheninae as the outgroup. The analysis yielded nine equally parsimonious cladograms (47 steps, CI = $56, \mathrm{RI}=68$ ), and a strict consensus cladogram was calculated (51 steps, $\mathrm{CI}=56, \mathrm{RI}=61$ ). The result suggests that the phylogenetic relationships between genera within the subfamily are monophyletic, despite their ecological diversity. The strict consensus cladogram indicates that the genus Heibrianax is paraphyletic to Eubrianax. The monophyly of Heibrianax + Eubrianax is supported by three synapomorphic characters. Therefore, Heibrianax is regarded as a junior synonym of Eubrianax. The current article also deals with some members of Eubrianax, although they display significant difference from other representatives of the genus. The evolution of characters in the immature stages is discussed. Eubrianax pellucidus species group and E. serratus species group are treated. Eubrianax manakikikuse amamiensis Satô, 1965 is raised to specific rank. A new subspecies, Eubrianax manakikikuse kimurai ssp. nov., and a new species, Eubrianax serratus sp. nov., are described. Keys to genera of the subfamily, based on adults, larvae, pupae, and a checklist of the species are provided.
\end{abstract}

KEY WORDS Psephenidae, Eubrianacinae, systematics, phylogenetics

The EubrianacinaE IS a monogeneric subfamily of the family Psephenidae and is composed of about 50 species (Lee and Jäch 1995). The larvae live in the lotic environment and pupate above the water. The immature stages are well described (Blackwelder 1930, Jäch 1984); but no attempt has been made to use them in phylogenetic studies due to their disassociation with adults. Recent studies support the suprageneric classification of Eubrianacinae by associating adults with immatures. Lee et al. (1999a) redefined the type genus Eubrianax in a strict sense and described a new genus, Heibrianax, although larvae were not distinguishable. Lee et al. (1999b) also described the new genus, Mubrianax based on larval morphology and ecology. Jinbrianax (Lee et al. 1999c) was described and possesses some pleisomorphic characters not found in other known genera. The new genus Odontanax (Lee et al. 2000a) was described based on unexposed pupae, and the new genus Jaechanax (Lee et al. 2000b) was described based on the immature stages containing characters shared with Odontanax and Mubrianax.

In addition, we have found some species close to Eubrianax but that display significant differences in adults and larvae. Our main objective was to use evidence from the adult and immature stages to conduct a phylogenetic analysis of genera within the Eu-

\footnotetext{
${ }^{1}$ Department of Entomology, National Taiwan University, Taipei, 106 Taiwan.

${ }^{2}$ Laboratory of Nature Conservation, Graduate School of Nagoya Women's University, Mizuho-ku, Nagoya, 467-8610 Japan.
}

brianacinae, and to test monophyly of Eubrianax and Heibrianax by adding those problematic species. We have also tested some evolutionary hypotheses proposed by Lee et al. (1999b, 1999c, 2000a).

\section{Materials and Methods}

Measurements for specimens are given in millimeters ( $\mathrm{mm})$. In descriptions of the species of Eubrianax, measurements of antennomeres, mouth parts, and body proportions are given as ratios $(\mathrm{LP}=$ pronotal length, WP = pronotal width, LE = elytral length, $\mathrm{WE}=$ elytral width).

Specimens examined are deposited in the following institutions (letter codes according to Arnett et al. (1993), except CNJ and NWU): BPBM, Bernice P. Bishop Museum, Honolulu; CNJ, Collection of Nakane, Japan (now in NSMT); NHMB, Naturhistorisches Museum, Basel; NHMW, Naturhistroisches Musem, Wien; NSMT, National Science Museum, Tokyo; NTUC, National Taiwan University, Taipei; NWU, Nagoya Women's University, Nagoya. Checklist of the Species and their Distributions of Eubrianacinae.

The species examined are shown in the Checklist of the Species and Their Distributions of Eubrianacinae section. The immature stages of one species for each genus are available for study (except Eubrianax): Jinbrianax jaechi Lee et al. 1999c, Odontanax dohertyi (Pic 1915), Mubrianax robustior (Pic 1928), Jaechanax dentatus Lee et al. 2000b, and Heibrianax secretus Lee 

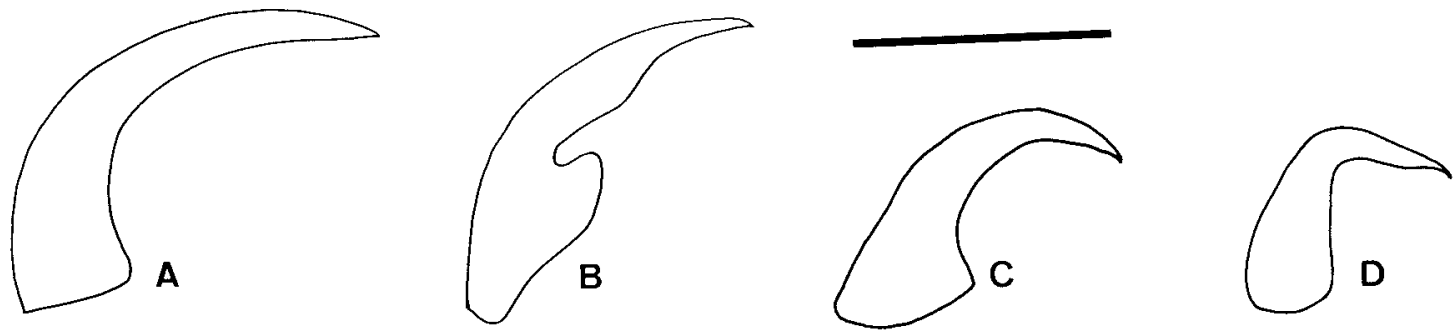

Fig. 1. Tarsal claws. (A) Jaechanax insignis (Fairmaire). (B) Mubrianax robustior (Pic). (C) Eubrianax tarokoensis Lee \& Yang. (D) Eubrianax granicollis Lewis. Scale bar $=0.1 \mathrm{~mm}$.

et al. 1999a. Mataeopsephus taiwanicus Lee et al. 1990 was examined and selected as an outgroup. In addition, we used some larvae that were not associated with adults.

Eubrianacinae and its Phylogenetic Relations within Psephenidae. Although subfamilies within the Psephenidae are well defined, only some characters in the immature stages reveal phylogenetic relationships. The respiratory system of larval Eubrianacinae is similar to that of the Psepheninae (Hinton 1955). The tracheal system is amphineustic in all instars, and the functional spiracles are located on the mesothorax and the eighth abdominal segment, but those on the eighth abdominal segment are different in structure between both subfamilies. Although ventral gills are found in both subfamilies, their structure, position, and number differ. Thus, the mesothoracic spiracle is considered synapomorphic for the Psepheninae and Eubrianacinae; spiracles of the eighth abdominal segment and ventral gills are autapomorphic for the Psepheninae and Eubrianacinae. The two additional synapomorphic characters for Psepheninae and Eubrianacinae are found herein: the presence of posterior plates on all three thoracic segments, and the presence of costal lines. Thus, the subfamily Psepheninae is a probable sister group of the Eubrinacinae.

Larvae of Mubrianax and Jaechanax (Fig. 5) are adapted for a xylophagous lifestyle. The body is oblong to adhere tightly to slender twigs. Compared with other members of the Eubrianacinae, the mandibles are thicker and have apical teeth for feeding on wood (Fig. $3 \mathrm{C}$ and D).

Pupae of Eubrianacinae are unique and apomorphic because they are the only known insect pupae with a metapneustic respiratory system (Hinton 1966). Hinton (1955) stated the following: "the Eubrianax retain the last larval cuticle over the pupa, although the last three segments of the larval cuticle are shed. The shed segments of the larval cuticle are replaced by heavily sclerotized pupal structures which, from a dorsal view, so closely resemble the missing part of the larval cuticle that the latter appears to be complete." The pupae have previously been thought to be apneusitic (Hinton 1955) because no ordinary spiracular opening
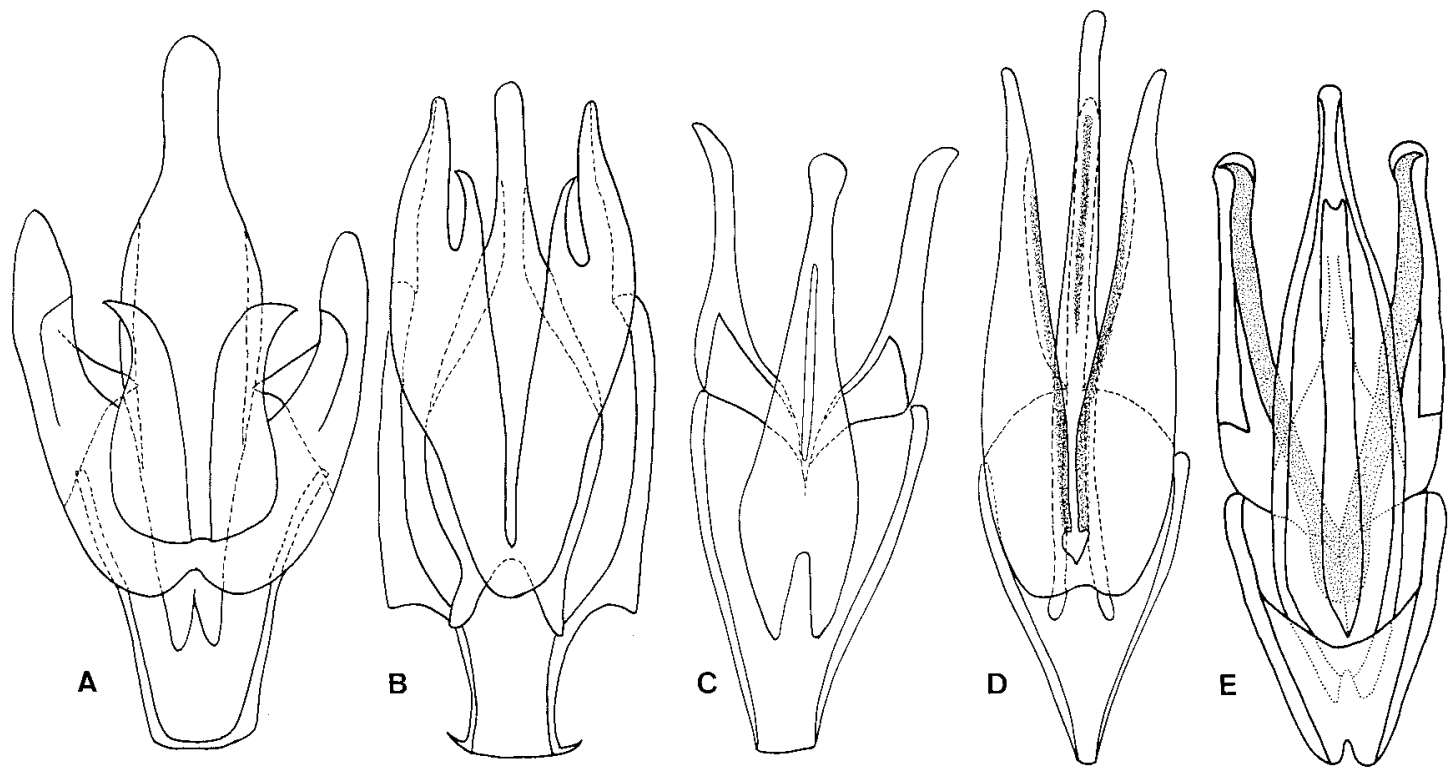

Fig. 2. Aedeagi. (A) Jinbrianax apicalis (Pic). (B) Odontanax dohertyi (Pic). (C) Mubrianax robustior (Pic) (D) Jaechanax insignis (Fairmaire). (E) Eubrianax secretus Lee et al. 

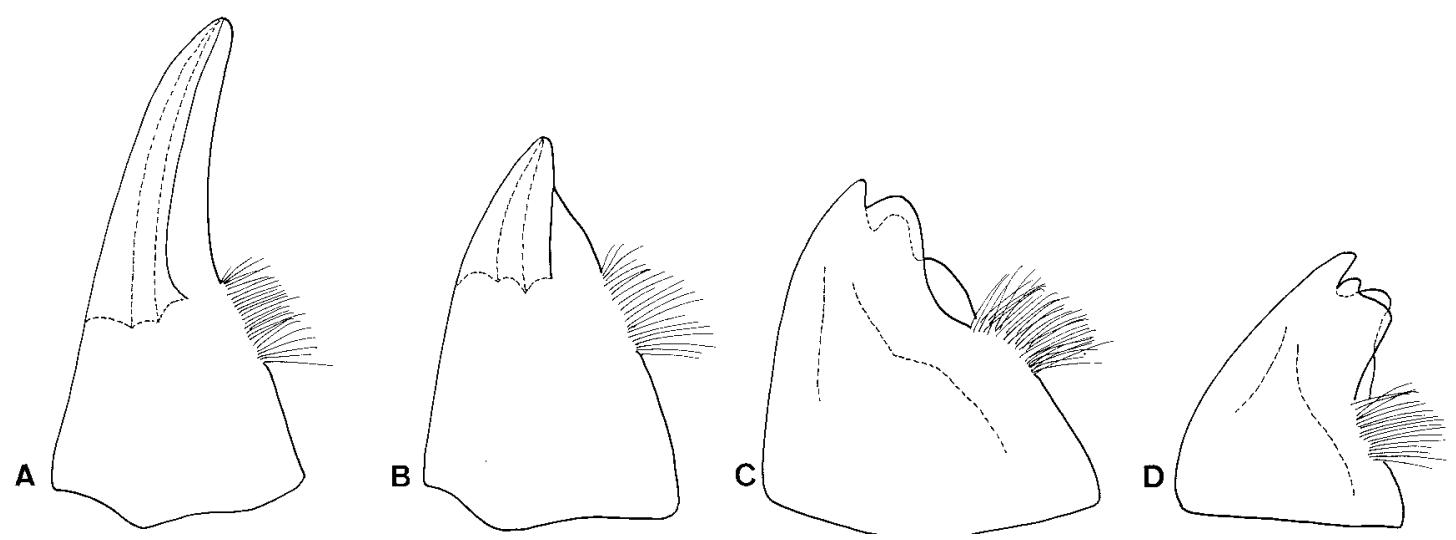

Fig. 3. Larval mandibles. (A) Eubrianax tarokoensis Lee \& Yang. (B) Eubrianax pellucidus Lewis. (C) Jaechanax sp. (D) Mubrianax robustior (Pic). Scale bar $=0.1 \mathrm{~mm}$.

was observed. In fact, the trachea connect to many small openings scattered widely across small tubercles. This condition does not resemble that other of beetle pupae nor any other known insect (Hinton 1966).

Hinton (1966) examined pupae of Asian, American, and African species and found there were no significant differences between them. Lee et al. (2000a, $2000 \mathrm{~b})$ found that Odontanax and Jaechanax have unexposed pupae, rather different from exposed pupae (Hinton 1966). In mature larvae of Odontanax and Jaechanax (Figs. 4C and 5A), the pleurites of abdominal segments 6 and 7 are not tightly connected; slender crevices are present between the posterior margins of abdominal pleurites 6 and the anterior margins of abdominal pleurites 7. During pupation, the last three abdominal terga of the larva are not shed and the whole pupa is covered by this larval skin. The openings of the spiracles on the pupal abdominal tergum 7 are reduced except those on the outward margins (Fig. 7 $\mathrm{D}$ and $\mathrm{E}$ ), which project from the crevices in the larval skin. All three apical abdominal terga are sclerotized slightly, except the outward margins of the abdominal tergum 7.

Terminal Taxa. The cladistic analysis involves 11 terminal taxa, including an outgroup. Species within genera are invariant for characters listed here except for those of Eubrianax, which are listed separately here.

Characters and Polarity. Twenty-one morphological characters were selected: eight from adult, nine from larvae, four from pupae. Character states were polarized by the outgroup comparison method (Watrous and Wheeler 1981). Psepheninae (Mataeopsephus) was selected as the outgroup. However, because all pupal characters are autapomorphic, polarization was based on a hypothetical outgroup. Transformation series were coded in discrete binary and multistate characters. When multistate characters could be ordered by morphological continuity, which implied a logical linear sequence of intermediate states, they were treated as additive; otherwise, they were treated as nonadditive (unordered), which re-

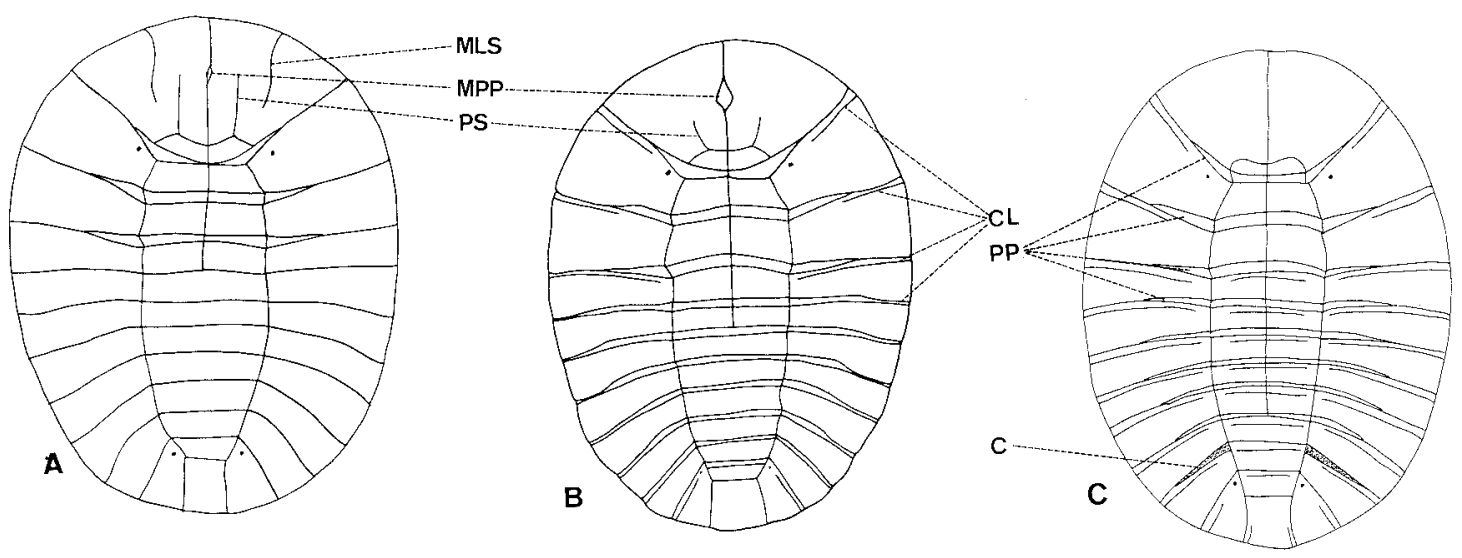

Fig. 4. Larvae. (A) Jinbrianax jaechi Lee et al. (B) Eubrianax tarokoensis Lee \& Yang. (C) Odontanax dohertyi (Pic). C, crevice between abdominal segments 6 and 7; CL, costal lines; MLS, midpronotal longitudinal sulcus; MPP, middorsal pronotal plate; PP, posterior plate; PS, periocullar sulcus. 


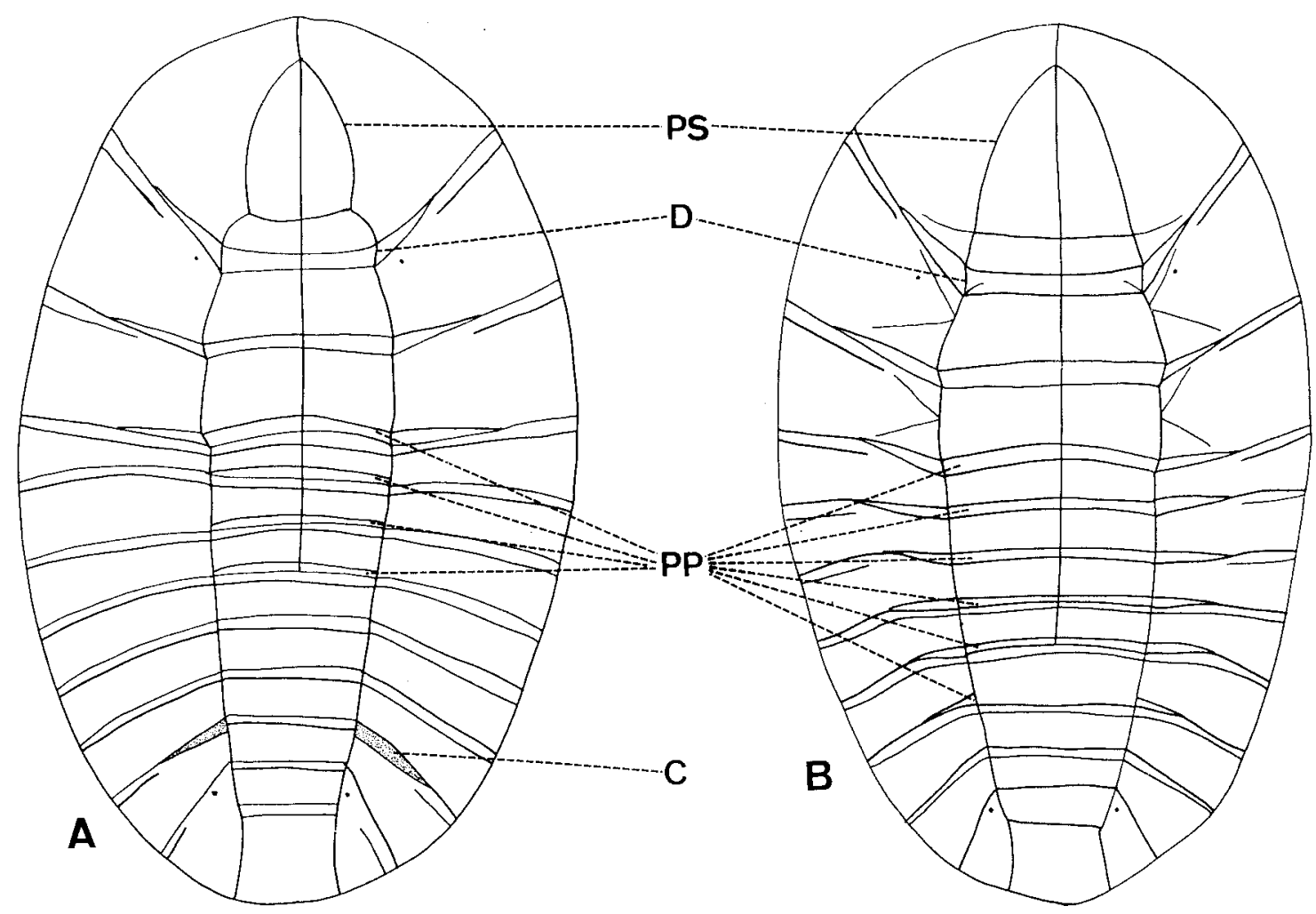

Fig. 5. Larvae. (A) Jaechanax dentatus Lee, Sato, and Yang. (B) Mubrianax robustior (Pic). C, crevice between abdominal segments 6 and 7; D, dividing sulcus at posterior plates on pronothorax; PP, posterior plate; PS, periocullar sulcus.

sults in the equal cost of only one step for the transformation between any of its states.

A missing data code "?," is used when the character state was not applicable (autapomorphic or missing) or when the terminal taxon was polymorphic for the character.

Cladistic Analysis. Parsimony analysis was performed using Hennig86 (Farris 1988). Tree length and consistency and retention indices were calculated excluding autapomorphies of Eubrianacinae to avoid artificially increasing these indices. When the analysis yielded more than one cladogram, a strict consensus tree was calculated with the Nelsen option of Hennig86. Clados (Nixon 1992) was used for tree manipulations and tracing character evolution.

We selected eight characters from adults (1-8), nine from larvae (9-17), and four from pupae (1821); the data matrix is shown as Appendix 1.

1. Male Antennae $(\mathrm{CI}=40, \mathrm{RI}=25)$. (0) Serrate (Fig. 16C); (1) pectinate, antennal rami originating from apices on segments 5 to 10 (Lee et al. 1999a; Figs. 7 and 11); (2) pecinate, antennal rami originating from bases or middles on segments 5 to 7 (Figs. 10C, 12D, $13 \mathrm{E}$, and $15 \mathrm{C}$ ). Serrate antennae are only found in Eubrianax serratus. The intermediate apomorphic condition occurs in Jinbrianax, Mubrianax, Eubrianax tarokoensis, and Heibrianax. The character was coded as polymorphic for Odontanax. This multistate character was treated as nonadditive.

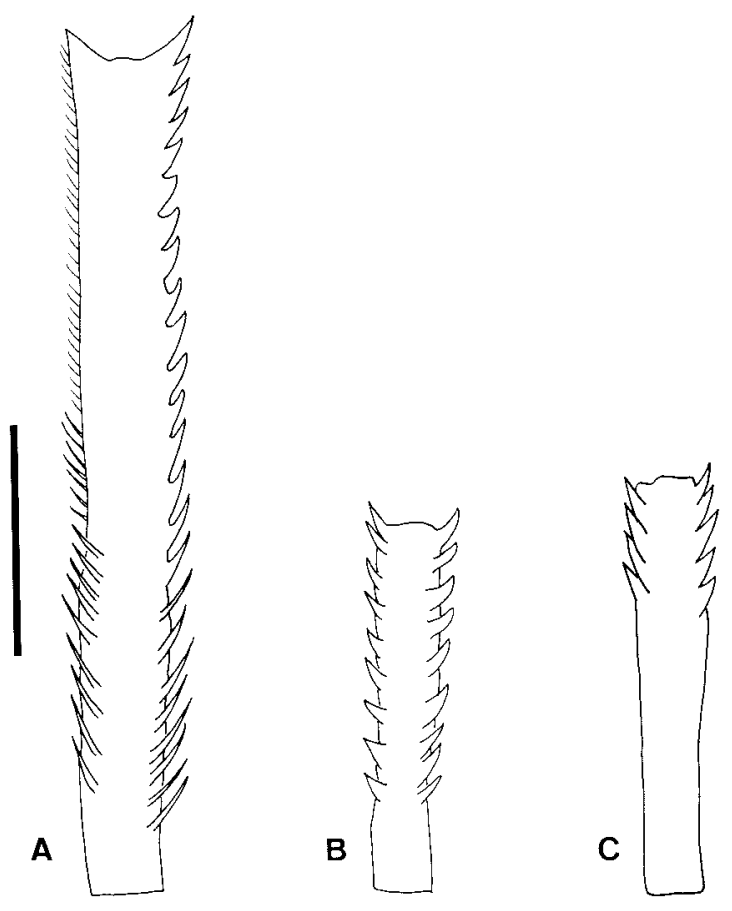

Fig. 6. Basal pieces of marginal peg setae. (A) Jinbrianax jaechi Lee et al. (B) Mubrianax robustior (Pic). (C) Jaechanax sp. Scale bar $=0.1 \mathrm{~mm}$. 


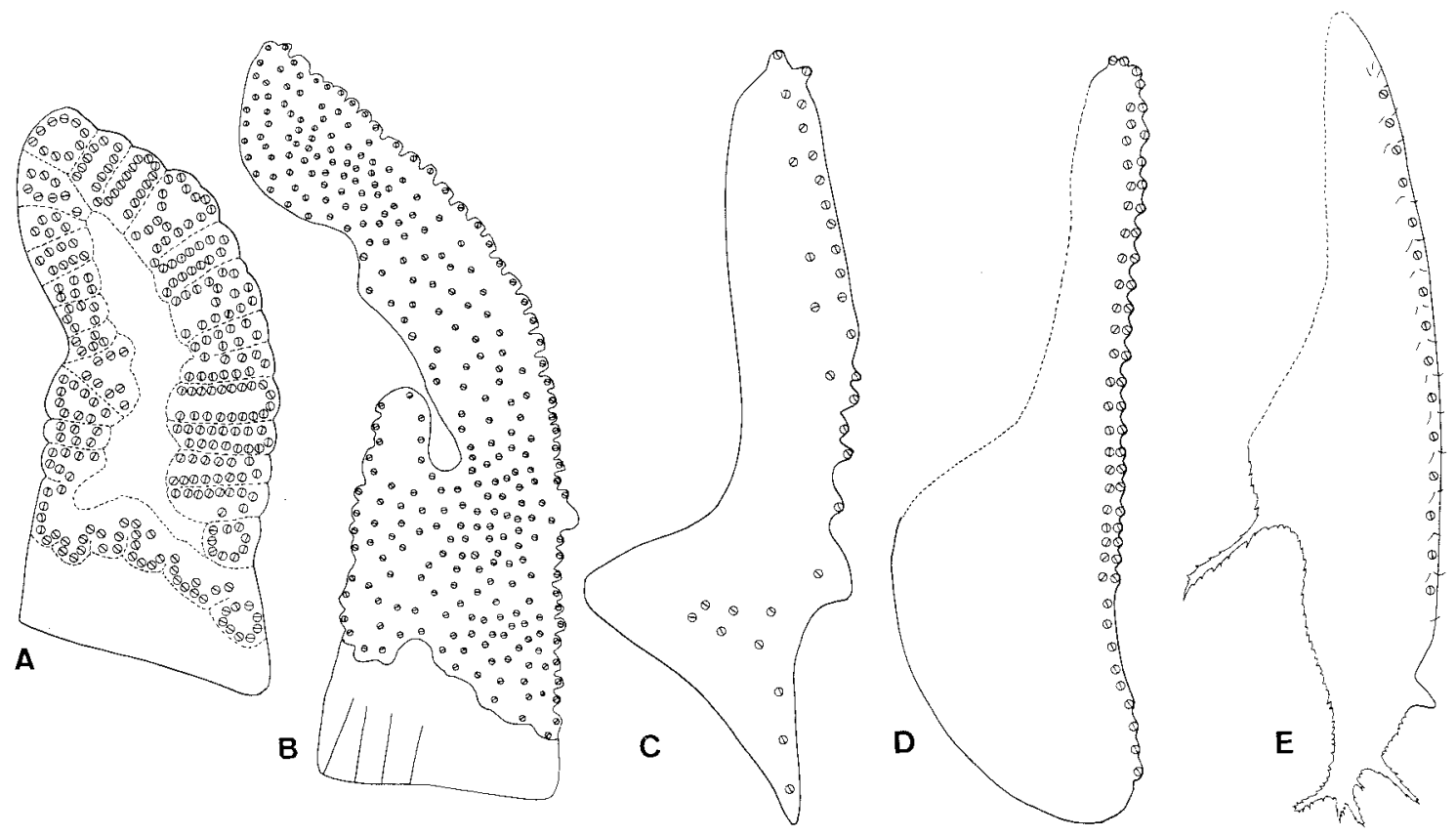

Fig. 7. Pupal spiracles. (A) Jinbrianax jaechi Lee, Sato, and Yang. (B) Mubrianax robustior (Pic). (C) Eubrianax serratus sp. n. (D) Odontanax dohertyi (Pic). (E) Jaechanax dentatus Lee, Sato, and Yang.

2. Apex of Prosternal Process $(\mathrm{CI}=33, \mathrm{RI}=0)$. (0) Dilated; (1) acute. The apex of the proternal process is dilated in Odontanax and Heibrianax. The character was coded as polymorphic for Mubrianax, and inapplicable for Eubrianax serratus, because the apex of its posternal process is truncate.

3. Number of Apical Spurs on Pro-, Meso- and Metatibiae (CI and RI = 100). (0) 2-2-2; (1) 2-1-1. The number of apical spurs on meso- and metatibiae is reduced to one in all genera of Eubrinacinae except Jinbrianax.

4. Pulvilli at Tarsal Claws (CI and RI $=100)$. (0) Absent; (1) membranous, (2) sclerotized and well developed. Membranous pulvilli are found only in Jaechanax. They are well developed in all species of Eubrianax and Heibrianax. This character was treated as additive and multistate.

5. Tarsal Claws (CI and RI $=100)$. (1) Long and slightly curved (Fig. 1 A and B); (1) short, moderately or strongly curved (Fig. $1 \mathrm{C}$ and D). The apomorphic condition appears in all species of Eubrianax and Heibrianax.

6. Mesal Margins of Parameres $(\mathrm{CI}=50, \mathrm{RI}=0)$. (0) Smooth (Fig. 2 C-E); (1) with one pair of processes (Fig. $2 \mathrm{~A}$ and B). The paired processes on the mesal margins of the parameres occur in Jinbrianax and Odontanax.

7. Mesal Margins of Parameres $(\mathrm{CI}$ and $\mathrm{RI}=100)$. (0) Moderately sclerotized (Fig. 2 A-C); (1) strongly sclerotized (Figs. $2 \mathrm{D}$ and E; 10B, 12C, 13C, 15B, and 16B). The slender darkened bands along the mesal margins of parameres appear in Jaechanax, Heibrianax, and all species of Eubrianax.
8. Apices of Parameres (CI and RI $=100)$. (0) Without sclerites covered (Fig. 2 A-D); (1) with rounded sclerites covered (Figs. 2E, 10B, 12C, 13C, $15 \mathrm{~B}$, and 16B). The apomorphic condition occurs in all species of Eubrianax and Heibrianax.

9. Mandibles $(\mathrm{CI}=50, \mathrm{RI}=0)$. (0) Algae-feeding (Fig. $3 \mathrm{~A}$ and B); (1) xylophagous (Fig. $3 \mathrm{C}$ and D). All but Mubrianax and Jaechanax have flattened mandibles adapted for feeding on algae. Larvae of $\mathrm{Mu}$ brianax and Jaechanax have wide and apically toothed mandibles suitable for feeding on wood.

10. Middorsal Pronotal Plate $(\mathrm{CI}=33, \mathrm{RI}=20)$. (0) Absent (Figs. 4C and 11); (1) incomplete (Figs. $5 \mathrm{~A}$ and B, 14); (2) well developed (Fig. 4 A and B, 17). The middorsal pronotal plate is found in Jinbrianax, Eubrianax tarokoensis, E. serratus, and Heibrianax. It is incomplete in Eubrianax pellucidus, E. amamiensis (Fig. 9 B-D); sometimes combined with periocullar sulci in Mubrianax and Jaechanax (Fig. 5 A and B). This multistate character was coded as nonadditive.

11. Mid-Pronotal Longitudinal Sulci (CI and RI = 100). (0) Present (Fig. 4A); (1) absent (Fig. 4 B and C). Mid-pronotal longitudinal sulci are only found in Jinbrianax.zzz.zzz.

12. Dividing Sulci at Posterior Plates on Prothorax $(\mathrm{CI}=33, \mathrm{RI}=33)$. (0) Absent (Figs. $4 \mathrm{~A}$ and B, 11, 17); (1) present (Figs. 4C, $5 \mathrm{~A}$ and B, 14). The prosterior plates on the prothorax are divided by the basal margins of the pleurites in Odontanax, Mubrianax, Jaechanax, and Eubrianax amamiensis.

13. Posterior Plates on Abdominal Terga ( $\mathrm{CI}=40$, $\mathrm{RI}=0$ ). (0) Absent (Fig. $4 \mathrm{~A}$ and B); (1) present on abdominal segments 1 to 4 (Figs. 4C, 5B, and 11); (2) 


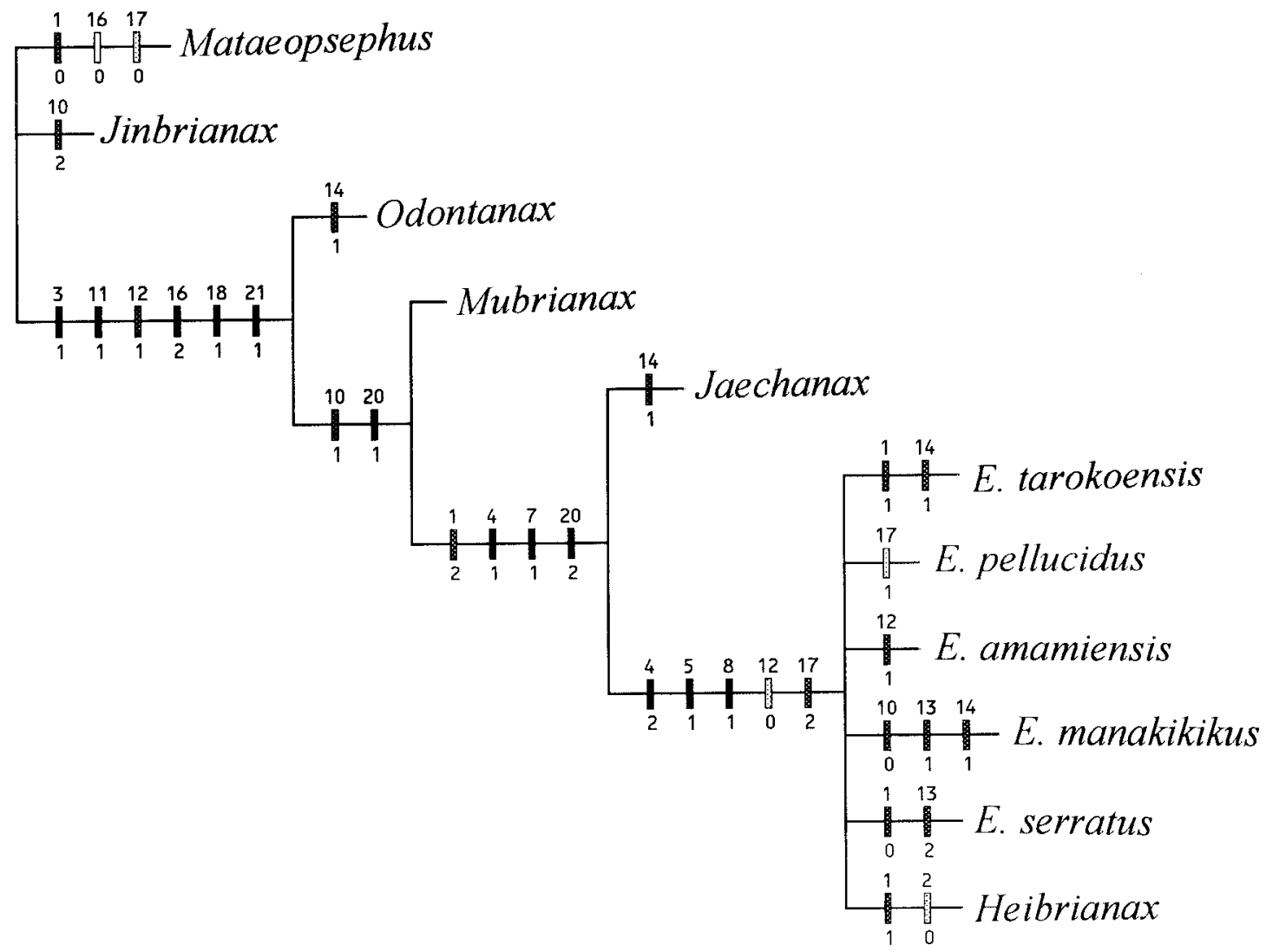

Fig. 8. Strict consensus tree of the nine most parsimonious cladograms. E. = Eubrianax.

present on main plates of abdominal segments 1 to 3 (Figs. 5A and 17). The posterior plates can be found on abdominal terga 1-4 in Odontanax, Mubrianax, and Eubrianax manakikikuse; on main plates of the abdominal segments 1 to 3 in Jaechanax and Eubrianax serratus. This multistate character was treated as nonadditive.

14. Crevices between Abdominal Segments 6 and 7 $(\mathrm{CI}=25, \mathrm{RI}=0)$. (0) Absent (Figs. $4 \mathrm{~A}$ and B, 5B, 11, 14, 17). (1) Present (Figs. 4C and 5A). Crevices between abdominal segments 6 and 7 are found in Odontannax and Jaechanax. They are also found in some species of Eubrianax, although they are not as prominent as those of Odontannax and Jaechanax.

15. Body Form ( $\mathrm{CI}=50, \mathrm{RI}=0)$. (0) Oval (Figs. 4, 11, and 17); (1) oblong (Fig. 5). The oblong body form is found in Mubrianax and Jaechanax.zzz.zzz.

16. Sides of Basal Pieces of Marginal Peg Setae (ci and $\mathrm{ri}=100)$. (0) Smooth; (1) with one side toothed (Fig. 6A); (2) with both sides toothed (Fig. 6 B and C). Sides of basal pieces of marginal peg setae are smooth in the outgroup. The intermediate apomorphic condition is found only in Jinbrianax. This multistate character was treated as additive.
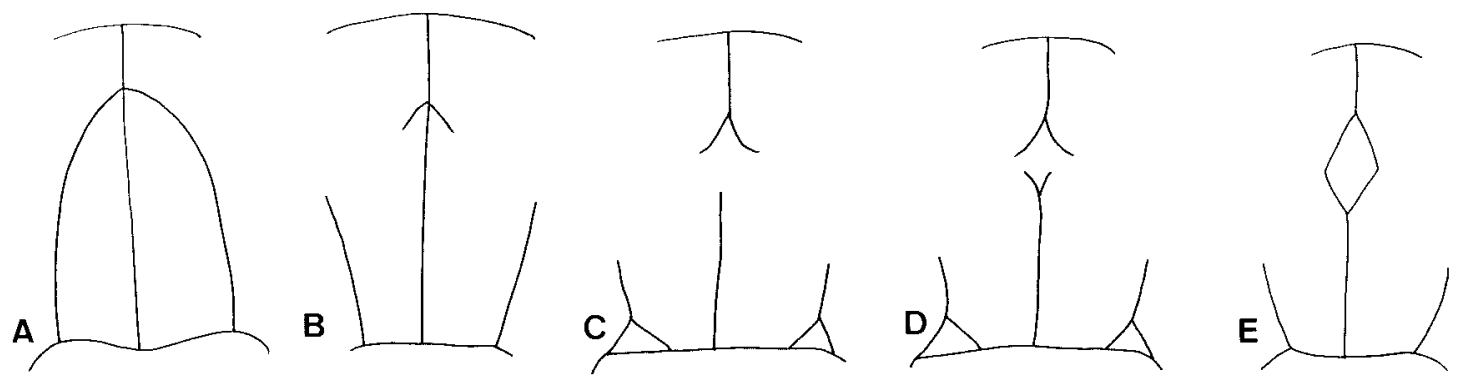

Fig. 9. Evolutionary trend from the apically conjoined periocullar sulci to the complete middorsal pronotal plate. (A) Mubrianax robustior (Pic). (B) Eubrianax pellucidus Lewis. (C) Eubrianax amamiensis kimura ssp. n. (D) Eubrianax amamiensis amamiensis Satô. (E) Eubrianax tarokoensis Lee \& Yang. 

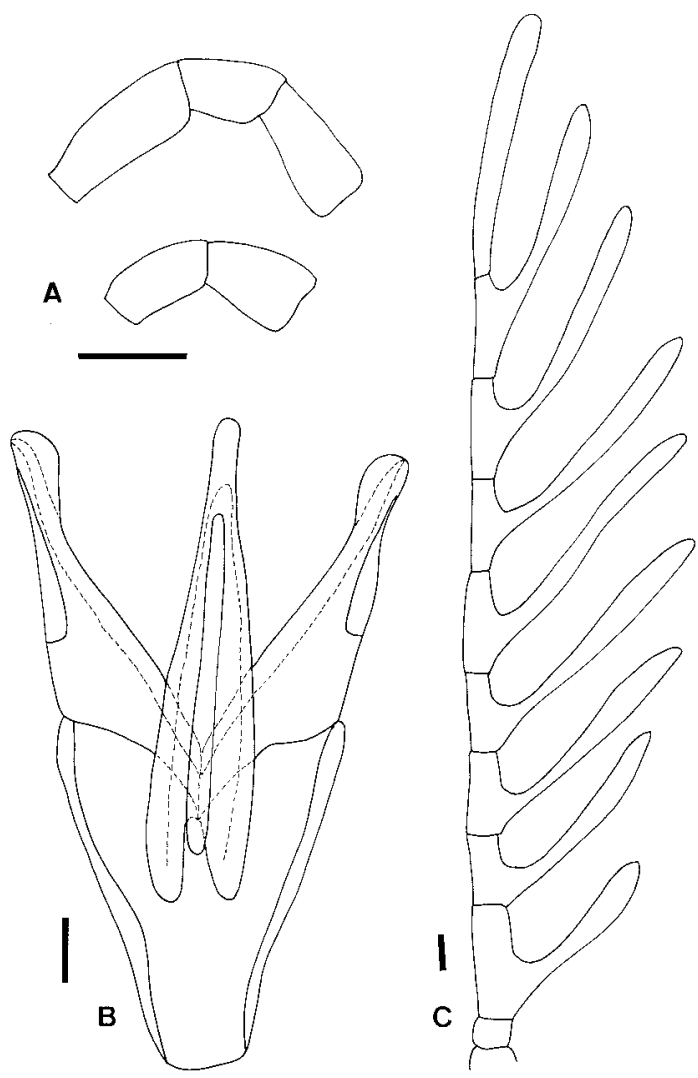

Fig. 10. Eubrianax manakikikuse Satô. (A) Maxillary (upper) and labial (lower) palpus. (B) Aedeagus. (C) Male antenna. Scale bar $=0.1 \mathrm{~mm}$.

17. Apical Setae at Basal Pieces of Marginal Peg Setae $(\mathrm{CI}=66, \mathrm{RI}=75)$. (0) Absent; (1) paired, oval or lanceolate (Fig. 12B); (2) paired, apically combshaped (Lee et al. 1999c; Fig. 5). The outgroup does not have this character. The apomorphic condition appears in Eubrianax flavus, E. amamiensis, E. manakikikuse, E. serratus, and Heibrianax. This multistate character was treated as additive.

18. Outward Margins of Spiracles (CI and RI = 100). (0) Without openings (Fig. 7A); (1) with rows of openings (Fig. $7 \mathrm{~A}-\mathrm{E}$ ). The pleisomorphic condition appears in only Jinbrianax.

19. Distribution Pattern of Openings of Spiracles $(\mathrm{CI}=66, \mathrm{RI}=50) .(0)$ Confined to vermiculations and surrounding spiracles (Fig. 7A); (1) reduced except those on outward margins of spiracles (Fig. 7 D and E); (2) scattered or random (Fig. 7 B and C). In unexposed pupae of Odontanax and Jaechanax, the spiracles and openings are reduced except the outward margins. The openings of spiracles are scatterd or random on the spiracles in Mubrianax, Heibrianax, and all species of Eubrianax. This multistate character was treated as nonadditive.

20. Outward Margin of Each Spiracle (CI and RI = 100). (0) Without processes (Fig. 7 A and D); (1) with one process near base (Fig. 7B); (2) emarginate be-

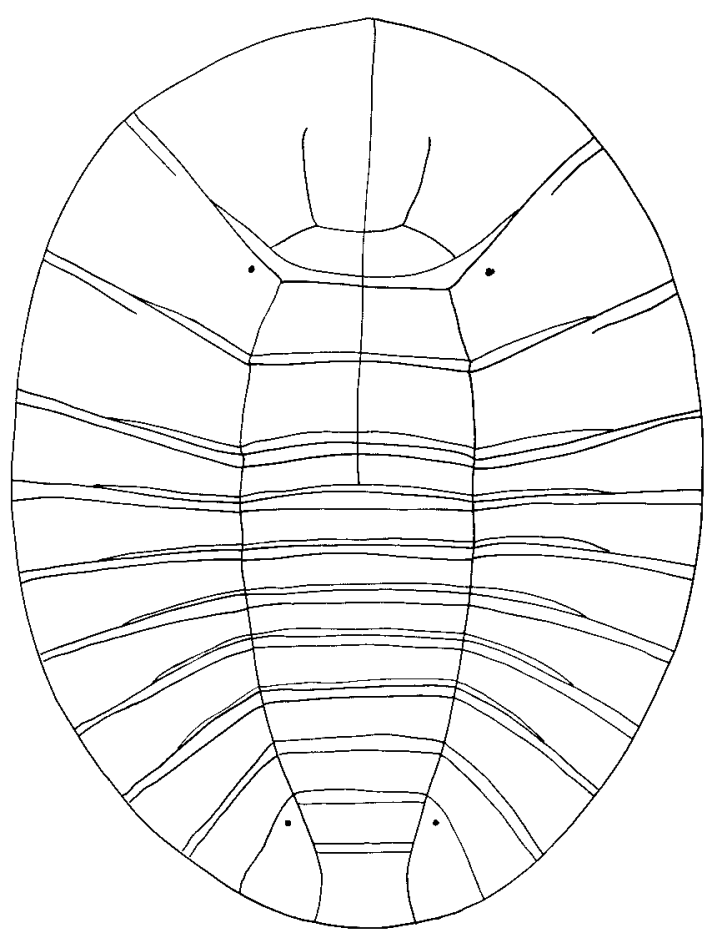

Fig. 11. Eubrianax manakikikuse Satô, larva.

hind the process (Fig. $7 \mathrm{C}$ and $\mathrm{E}$ ). The pleisomorphic condition appears in Jinbrianax and Odontanax; the apomorphic condition appears in Jaechanax, Heibrianax, and all species of Eubrianax. This multistate character was treated as additive.

21. Posterior Margins of Last Three Abdominal Terga (CI and RI = 100). (0) With true setae (Lee et al. 1999c; Fig. 15); (1) marginal extension (Lee et al. 1999b; Fig. 4; Lee et al. 1999c; Fig. 14). The pleisomorphic condition appears in only Jinbrianax.

Phylogenetic Results. Although the phylogenetic analysis yielded nine most parsimonious cladograms, all changes were restricted to relations between Heibrianax and members of Eubrianax. Thus, when the strict consensus cladogram was preformed, there would be one unresolved clade (Fig. 8).

Position of Jinbrianax. The cladogram (Fig. 8) is consistent with the hypothesis that Jinbrianax is the most primitive genus within Eubrianacinae, indicated by three primitive characters (excluding pupal stages): the number of the apical spurs on the pro-, meso-, and metatibiae; 2-2-2 (3.0) in adults; presence of the mid-pronotal longitudinal sulci (11.0) and only one side of the basal pieces of the marginal peg setae with teeth (17.1) in larvae.

Position of Odontanax. Monophyly of "Odontanax + Mubrianax + Jaechanax + Heibrianax + Eubrianax" is supported by five synapomorphic characters in all stages: the number of the apical spurs on the pro-, meso-, and metatibiae; 2-1-1 (3.1) in adults; absence of the mid-pronotal longitudinal sulci (11.1), and both sides of the basal pieces of the marginal peg 

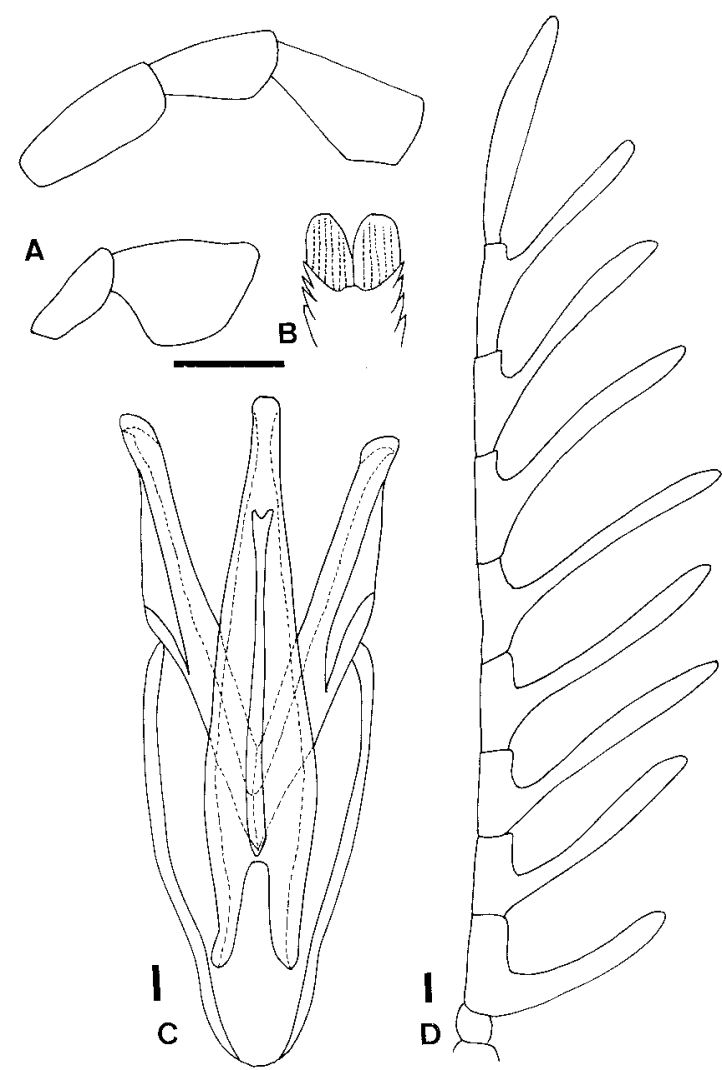

Fig. 12. Eubrianax pellucidus Lewis. (A) Maxillary (upper) and labial (lower) palpus. (B) Apex of basal piece of marginal peg seta, larva. (C) Aedeagus. (D) Male antenna. Scale bar $=0.1 \mathrm{~mm}$.

setae with teeth (17.2) in larvae; the outward margins of spiracles with rows of openings (18.1); and posterior margins of last three abdominal terga without setae (21.1). The latter two characters may result from the appearance the unexposed pupae. Lee et al. (2000a) supposed that an unexposed pupa had a selective advantage by recycling the cuticles of the last three abdominal terga.

Position of Mubrianax. Monophyly of "Mubrianax + Jaechanax + Eubrianax + Heibrianax" is supported by the presence of one process near the base of the outward margin of each spiracle in pupae (16.1). This synapomorphic character may be caused by recovery of the exposed pupae based the following explanation. Compared with the pupae of Jinbrianax and $\mathrm{Mu}$ brianax, the latter lacks some complicated structures as in Jinbrianax, e.g., areas occupied by openings are raised and extend outside so that the entire spiracles are larger than the larval skin. The synapomorphic character appears to prevent the three apical pupal terga from pushing inside the larval skin when $M u$ brianax has evolved as exposed pupae. In addition, pupae of Mubrianax have the most and smallest openings within the Eubrinacinae, about nine times those of Eubrianax edwardsii compared with similar body size

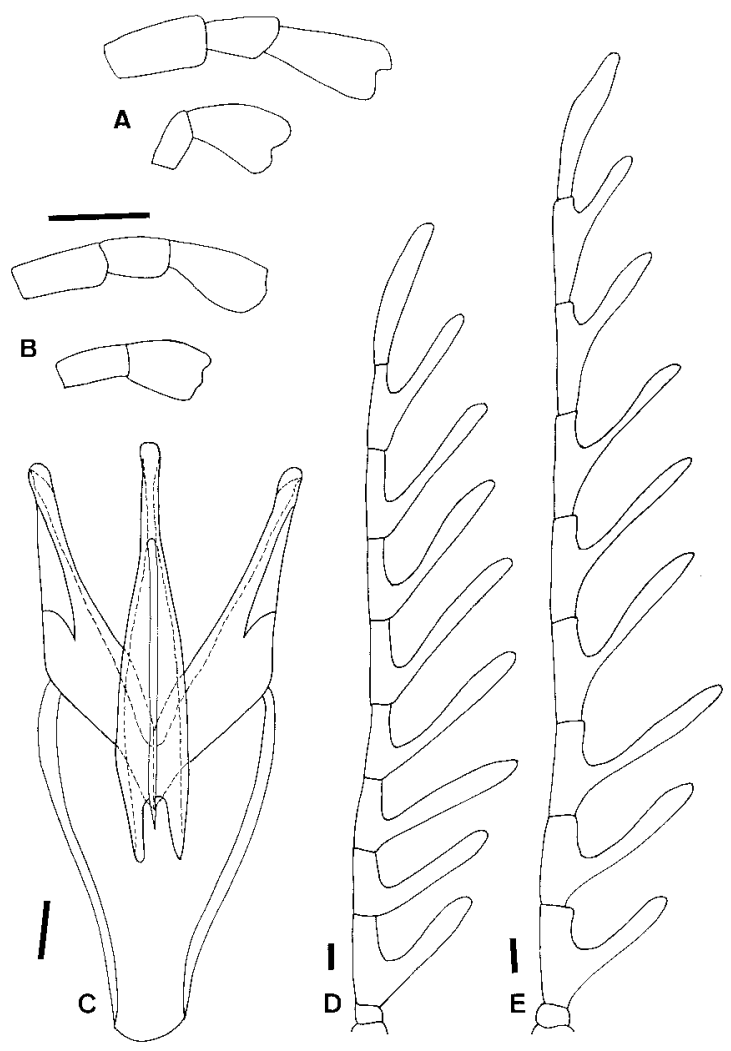

Fig. 13. Eubrianax amamiensis amamiensis Satô (B, C, D) and Eubrianax amamiensis kimura ssp. n. (A, E). (A, B) Maxillary (upper) and labial (lower) palpus. (C) Aedeagus. $(\mathrm{D}, \mathrm{E})$ Male antenna. Scale bar $=0.1 \mathrm{~mm}$.

in males. This suggests that larvae of Mubrianax can pupate under water.

Position of Jaechanax. Immature stages of Jaechanax share some characters with Odontanax and Mubrianax. The larva is oblong (15.1) and has the periocellar sulci conjoined apically (10.1) as in Mubrianax. The unexposed pupa and the presence of crevices between abdominal terga 6 and 7 in larvae (14.1) are also found in Odontanax. These characters make it difficult to determine which genus is the sister group of Jaechanax. However, comparing the unexposed pupae of Odontanax and Jaechanax, the latter differs by having one process near the base of each spiracle (20.1) that is functional for exposed pupae. This indicates there must be at least one evolutionary event producing exposed pupae in both genera. In addition, the distribution patterns of openings on exposed pupae are distinct among Jinbrianax, Mubrianax, and Eubrianax. This implies that the evolutionary event causing unexposed pupae has happened more than once because the presence of unexposed pupae involves reducing openings of the spiracles, except those at the outward margins. Both characters are consistent with the present phylogenetic hypothesis that Mubrianax is the sister taxon of Jaechanax.

The oblong body shape (15.1) and the xylophagous mandibles (9.1) in larvae are alternative evolutionary 


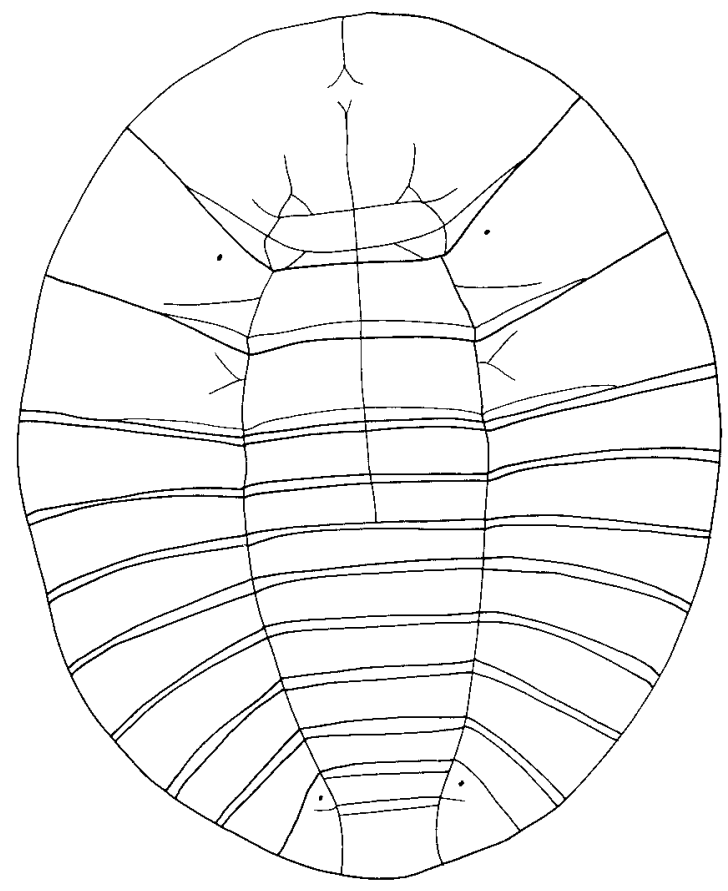

Fig. 14. Eubrianax amamiensis amamiensis Satô, larva.

events because both Jaechanax and Mubrianax are in a sister relationship. It takes the same number of steps either way: evolves parallel in both genera or is synapomorphic for both genera and reverse in Eubrianax and Heibrianax.

Monophyly of Jaechanax + Eubrianax + Heibrianax is supported by (1) the presence of pulvilli at tarsal claws $(4.1),(2)$ the strongly sclerotized mesal margins of the parameres (7.1) in adults, and (3) the outward margin of each spiracle being emarginate behind the process (20.2) in pupae. This latter synapomorphic character in pupae is interesting because it may be caused by the recurrence of unexposed pupae. The openings of spiracles above the process can be projected from the larvae skin; however, the ones behind the process would be reduced because they are not functional below the larval skin. This may be a possible cause for the emargination of the outward margin behind the process (20.2).

Monophyly of Heibrianax + Eubrianax. The present cladogram (Fig. 8) does not support the hypothesis of monophyly of Heibrianax, but that it is paraphyletic. Monophyly of Heibrianax + Eubrianax is supported by (1) having well-developed pulvilli on tarsal claws (4.2), (2) short and moderately curved tarsal claws (5.1), and (3) apex of each paramere with one rounded sclerites covered (8.1) in adults. Thus, we regard Heibrianx as a new junior synonym of Eubrianax.

Although adults of Eubrianax pellucidus, E. amaiensis, and E. manakikikkuse are similar, their larvae have some characters inconsistent with the other Eubrianax larvae. The phylogenetic analysis suggests that all three species should remain in the genus to maintain
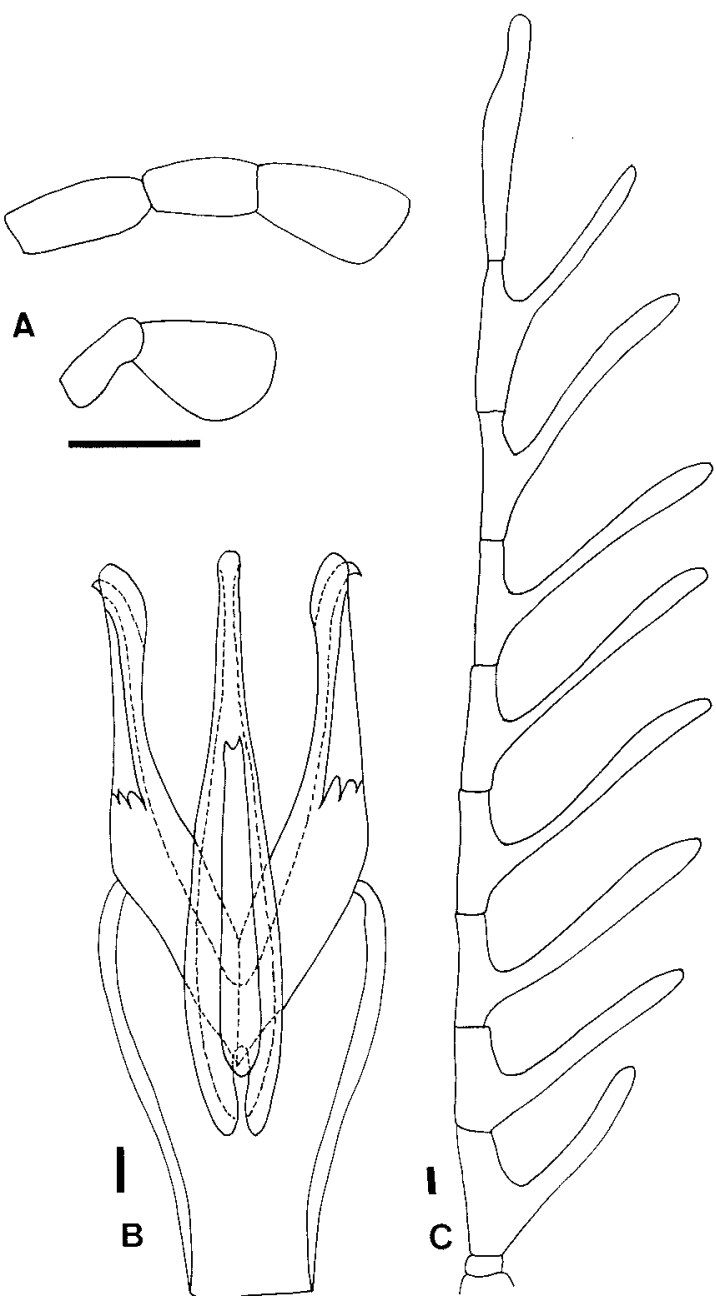

A
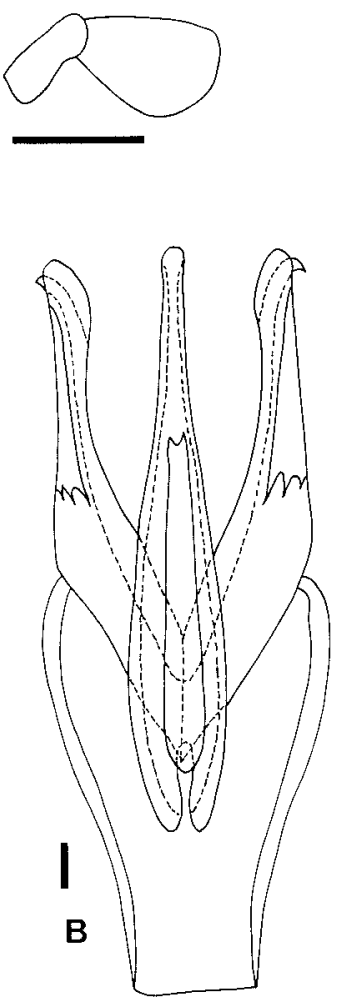

Fig. 15. Eubrianax insularis Nakane. (A) Maxillary (upper) and labial (lower) palpus. (B) Aedeagus. (C) Male antenna. Scale bar $=0.1 \mathrm{~mm}$.

its monophyly. A similar situation happens with $E$. serratus. Some evolutionary trends are revealed from the present cladogram: (1) The paired lanceolate apical setae at the basal pieces of margin peg setae tend to be multifidous apically $(17.1 \rightarrow 2)$, the primitive condition appears in E. pelludicus; (2) the dividing sulci of the posterior plates on the prothorax tend to be absent $(12.1 \rightarrow 0)$, the primitive condition appears in E. amamiensis; (3) the apically conjoined periocellar sulci tend to transform the middorsal pronotal plate $(10.1 \rightarrow 2)$, that the middorsal pronotal plate is incomplete in E. pellucidus and E. amamiensis. Both species provide good evidence to hypothesize the last trend. First, the apically conjoined periocellar sulci break up. The anterior part becomes the anterior sucli of the middorsal pronotal plate (E. pellucidus, Fig. 9B). The middorsal line in which the middorsal pronotal plate is located disappears (E. amamiensis kimurai, Fig. 9C). The posterior sulci appear (E. amamiensis amamiensis, Fig. 9D). Finally, the middorsal prontonal is complete 


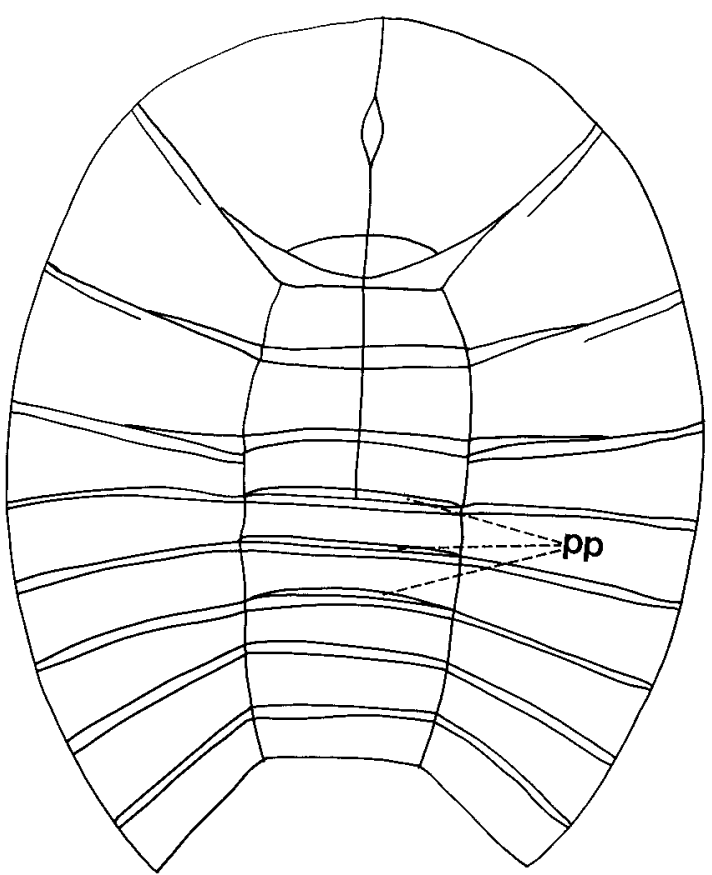

Fig. 16. Eubrianax serratus sp. n. (A) Maxillary (upper) and labial (lower) palpus. (B) Aedeagus. (C) Male antenna. (D) Female antenna. Scale bar $=0.1 \mathrm{~mm}$.

(E. tarokoensis, Fig. 9E). However, this evolutionary trend cannot reflect on Jinbrianax because it is homoplastic for Jinbrianax and Eubrianax. Moreover this character is rather different morphologically between Jinbrianax and Eubrianax.

Comparing the pupae of Jaechanax and other genera, Jaechanax has the fewest spiracular openings located only at the outward margins. Such a phenomenon contradicts Hinton's (1966) idea: "The pupa, unlike the larva of many Psephenidae, has no means of keeping the spiracular openings free of silt or other debris. Many separate openings over a large area seems to be the next best solution to the problem of preventing the spiracles from becoming totally blocked by debris." It provides a possible explanation why the pupa of Eubrianax is exposed. Because exposed pupae could use more openings than unexposed ones, such a evolutionary trend can benefit pupal survival.

Although the phylogenetic relationships between members of Eubrianax are not clear, they may be classified into several species groups based on adults. The E. granicollis species group comprises all species of Heibrianax (Lee et al. 1999a). The E. ramicornis species group is composed of all species of Eubrianax that Lee et al. (1999a) described. Eubrianax pellucidus, E. amamiensis, and E. manakikikuse are grouped as E. pellucidus species group. Eubrianax serratus should be separated into a discrete species group because it has a number of autapomorphies.

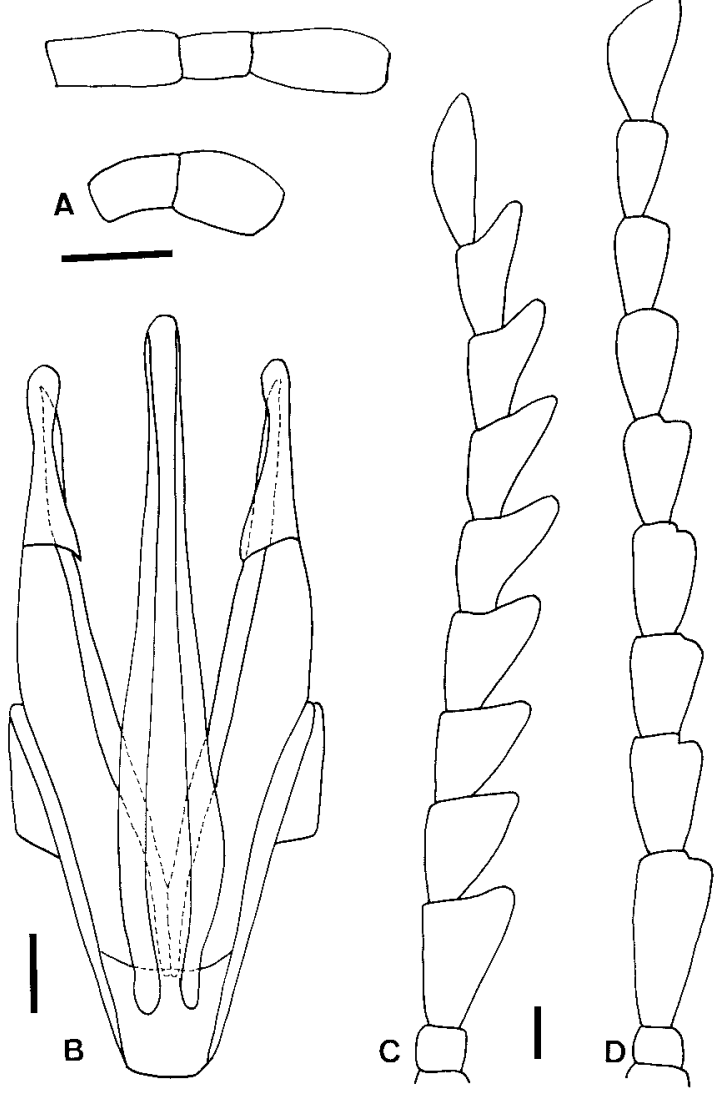

Fig. 17. Eubrianax serratus sp. n., larva.

\section{Systematic Account}

\section{Eubrianax pellucidus species group}

Adult Diagnosis. This species group differs from Eubrianax ramicollis species group by the male antennal rami beginning basally on segments 3 to 6 , from bases or middles on segments 7 to 10 .

Larval Diagnosis. Differs from Eubrianax ramicollis species group by either lacking or having incomplete middorsal pronotal plates.

Included Species. Eubrianax manakikikuse Satô, E. pellucidus Lewis, E. amamiensis Satô stat. nov., E. amamiensis kimurai ssp. nov., E. insularis Nakane.

\section{Eubrianax manakikikuse Satô}

(Figs. 10 and 11)

Eubrianax manakikikuse Satô, 1964: 35; - Satô 1965: 91; -Chûjô and Satô 1970: 15.

Eubrianax wulaiensis Lee and Yang, 1990: 80 (NTUC). syn. $n$.

Type Material. Eubrianax manakikikuse. HOLOTYPE: male, JAPAN: Ishigaki Is.: Mt. Banna-dake: 8-V63, Y. Arita, NWU (examined). 
Eubrianax wulaiensis. HOLOTYPE: male, TAIWAN: Wulai: 10-III-90, Lee. PARATYPES: 54 males, 10 females, same, NTUC (examined).

Male. 3.7-5.3 mm long, 2.6-3.8 mm wide. Coloration dark brown to black; but coxae and femora paler. Antennae with rami started from bases on segements 3-7 (Fig. 10C) from middles on segments 8 to 9 , from near apex on segment 10; relative lengths of ramus to antennomere from segment 3 to $10 \approx 1.5$ : 3.0: 3.0: 3.2: 2.7: 2.7: 2.6: 2.4. Maxillary palpus (Fig. 10A) slender; terminal segment apically dilated, apex truncate; relative lengths of segments 2 to $4 \approx 1.8$ : 1: 1.4. Labial palpus (Fig. 10A) small, $\approx 0.5$ times length of maxillary palpus; terminal segment similar to that of maxillary palpus; relative lengths of segment 2 to $3 \approx 1$ : 1.0. $\mathrm{WP} / \mathrm{LP}=2.2 . \mathrm{LE} / \mathrm{WE}=1.3 . \mathrm{WP} / \mathrm{WE}=0.7$.

Aedeagus (Fig. 10C). Aedeagus is 2.3 times as long as wide. Penis 0.7 times the length of aedeagus, apex slender, widened toward base, baso-lateral apophyses wide. Fibula slender, apex narrowed rounded. Parameres with ventral apophyses subtriangular.

Female. The female is $4.4-6.1 \mathrm{~mm}$ long, $2.6-3.8 \mathrm{~mm}$ wide. Coloration blackish brown except pronotum yellowish brown, medially darkened. WP/LP $=2.1$. $\mathrm{LE} / \mathrm{WE}=1.3 . \mathrm{WP} / \mathrm{WE}=0.6$.

Larval Diagnosis (Fig. 11). Similar to Eubrianax tarokoensis, but the middorsal pronotal plate is absent, the posterior plates on abdominal segments 1 to 5 appear, and the costal lines well develop on main plates of abdominal segments 1 and 9 .

Material Examined. JAPAN: Iriomote Is.: 1 male, 10-IV-69, Chujo, NWU; Ishigaki Is.: Omotoyama: 4 males, 12-13-V-75, Yano, NWU; 2 males, 13-15-V-75, Notsu, NWU; 1 female, Yoshihara, 5-IV-86, Sawai, NWU; TAIWAN: Kaohsung: Maolin: 1 male, 4 females, 17-II.-24-III-93, Lee, NTUC; Keelung: Nuannuan: 4 males, 4 females, III-93, Lee, NTUC; Taipei: Yangmingshan: 30 males, 8 males, 24-IV-91, Chang \& Lee, NTUC; Taitung: Chipen: 3 males, 1 female, 28-II-11III-93, Lee, NTUC; Taitung: Peiyu falls: 1 male, 2 females, 23-II-11-III-93, Lee, NTUC.

Distribution. Taiwan, Japan (Ishigaki and Iriomote islands).

\section{Eubrianax pellucidus Lewis} (Fig. 12)

Eubrianax pellucidus Lewis, 1895: 104. - Nakane 1948: 14. - Nakane: 1952: 41.

Eurianax sp. EA Gose 1957: 20 (larva)

Male. Male is $3.8 \mathrm{~mm}$ long, $2.2 \mathrm{~mm}$ wide. Coloration dark brown to black; but pronotum yellowish brwon with median longitudinal band; thoracic sterna and legs yellowish brown. Antennae (Fig. 12D) pectinate from segments 3 to 10; rami started from base on segments 3 to 6 , from middle on segments 6 to 10 ; relative lengths of ramus to antennomere from segment 3 to $10 \approx 1.5: 3.1: 3.0: 2.7: 2.6: 2.2: 2.3$ : 1.8. Maxillar palpus (Fig. 12A) slender; terminal apically dilated, apex rounded; relative lengths of segment 2 to $4 \approx 1.3$ : 1: 1.3. Labial palpus (Fig. $12 \mathrm{~A}$ ) small, $\approx 0.5$ times the length of maxillary palpus; terminal segment apically dilated, apex rounded; relativel lengths of segment 2 to $3 \approx 1: 1.4 . \mathrm{WP} / \mathrm{LP}=2.1 . \mathrm{LE} / \mathrm{WE}=1.3 . \mathrm{WP} / \mathrm{WE}=0.7$.

Aedeagus (Fig. 12C). Aedeagus 2.7 times as long as wide. Penis 0.9 times length of aedeagus, apex slender, widened toward base, baso-lateral apophyses wide. Fibula slender, apex emarginate. Ventral apophyses of parameres hook-like

Female. $5.0 \mathrm{~mm}$ long, $3.0 \mathrm{~mm}$ wide. Similar to males in color. $\mathrm{WP} / \mathrm{LP}=2.4 . \mathrm{LE} / \mathrm{WE}=1.4 . \mathrm{WP} / \mathrm{WE}=0.7$.

Adult Diagnosis. Easily distinguished from others by the bicolored pronotum and the yellowish brown legs.

Larval Diagnosis. Similar to Eubrianax manakikikuse, but posterior plates are absent on all abdominal segments, anterior half of the middorsal pronotal plate are present (Fig. 9B), and apical setae (Fig. 12B) are oval..

Material Examined. JAPAN: 1 female, Dando, Aichi Pref., 20-VII-69, Sato, NWU; 1 female, Kurokawa, NEchigo. 22-VII-72, Baba, NWU; 1 male, Kyushu, Hirado-Yasumandake, Nagasaki Pref., 31-VII-2-VIII74, Notsu, NWU; 3 males, MT, Amagi Naka-Izu, Shizuoka-Pref., 14-VII-90, Tsuyuki, NTUC, NWU; 1 female, MT, Ishizuchi, Ehime Pref., 3-VII-60, Ohbayashi, NWU; 1 male, Neo oppa, 7-10-VII-52, Ohira, NWU; 1 male. Tuzuro, Tokushima, 22-VII-65, Sakai, NWU; CHINA: Sichuan: 1 male, Guanxian, 600 m, 21-22-V89, Bocák, NHMB; 1 male, 700 m, 20-V-89, Kolibác, NHMB.

Distribution. Japan (Honshu, Shikoku, Kyushu), China (Sichuan).

\section{Eubrianax amamiensis Satô stat. nov.} (Figs. 13 and 14)

\section{Eubrianax manakikikuse amamiensis Satô, 1965: 92.}

Male. The male is 3.2-3.8 mm long, 2.1-2.3 mm wide. Coloration blackish brown. Antenna (Fig. 13D) with rami started from bases on segments 3 to 9 , from middle on segment 10; relative lengths ramus versus antennomere from segemtns 3 to $10 \approx 1.3$ : 2.0: 2.0: 2.1 : 2.0: 1.8: 1.6: 1.4. Maxillary palpus (Fig. 13B) slender; terminal apically dilated, apex irregular; relative lengths of segments 2 to $4 \approx 1.4$ : 1 : 1.6. Labial palpus (Fig. 13B) small, 0.5 times the length of maxillary palpus; terminal segment similar to that of mxillary palpus; relative lengths of segments 2 to $3 \approx 1$ : 1.1 . $\mathrm{WP} / \mathrm{LP}=1.8-1.9 . \mathrm{LE} / \mathrm{WE}=1.2 . \mathrm{WP} / \mathrm{WE}=0.7$.

Aedeagus (Fig. 13C). Aedeagus 2.5 times as long as wide. Penis 0.7 times length of aedeagus, apex very slender, widened toward base, baso-lateral apophyses slender. Fibula very slender, apex narrowed rounded. Parameres with ventral apophyses hook-like.

Adult Diagnosis. This species is close to Eubrianax manakikikuse, but differs by the shorter antennal rami.

Larval Diagnosis (Fig. 14). Similar to Eubrianax pelludicus, but the posterior half of the middorsal pronotal plate are present, not connected with anterior one; the middorsal line is absent between the anterior and posterior halves of middorsal pronotal 
plate; one additional sulcus is present arising from anterior margin of main plate of prothorax and apically conjoined with each periocellar sulcus; each posterior plate on prothorax separated by basal margins of pleurites, one obliquely longitudinal sulcus on each posterior plate; some derived sulci recognized on thoraces and abdomen; one arising from antero-lateral angles of main plates on prothorax, one obliquely transverse and arising from middle of basal margins of pleurites on mesothorax; on metathorax one paired $\mathrm{V}$-shaped one arising from the similar position as mesothrax; one transverse and arising from basal margins of pleurites between abdominal segments 8 and 9 .

Material Examined. JAPAN: 1 male, Amami-Oshima, Hatsuno, 14-VI-62, Sato, NWU; 1 male, Mikyo, Is. Tokunoshima, 12-IV-68, Tomokuni, NWU.

Distribution. Japan (Amami-Oshima and Tokunoshima islands).

\section{Eubrianax amamiensis kimurai sspn. nov.} (Fig. 13)

Type Material. Holotype, male, JAPAN: Okinawa, I-III-98, Lee, NHMW. PARATYPES: 2 males, 5 females, NHMW, NTUC, same data; 1 male, Hanejiohkawa, 26-III-97, Satô, NWU;1 male, Matsuda Ginoza V., 8-III-95, Kimura, NTUC; 1 female, Nago, Nago-shi, 1-IV-96, Yoshitomi, NWU; 2 males, Ohkuni-rindo, 4-V99, Utsunomiya, NWU; 1 male, Uehara, Ohgimi, 26XII-98, Sugimoto, NWU; 1 male, Yona, 24-25-III-64, Yoshimoto and Harrell, BPBM; 1 male, Yona, Kunigami-mura, 2-IV-96, Yoshitomi, NWU.; Taramajima: 1 male, 6-VI-96, Kimura, NTUC.

Male. Male 3.1-4.9 mm long, 2.0-2.4 mm wide. Coloration blackish brown, but pronotum yellowish brown, medially darkened; pro-, meso, and metasterna brown; trochanters, coxae, and femora yellowish brown. Antennae (Fig. 13E) pectinate from segments 3 to 10 ; rami stretched from base on segments 3 to 5 , from middle on segments 6 to 10; relative lengths of ramus to antennomere from segment 3 to $10 \approx 1.3: 1.7$ : 1.8: 1.7: 1.5: 1.4: 1.1: 1.0. Maxillary palpus (Fig. 13A) slender; terminal apically dilated, apex emarginate; relative lengths of segments 2 to $4 \approx 1.4$ : 1 : 1 .7. Labial palpus (Fig. 13A) small, 0.5 times the length of maxillary palpus; terminal segment similar to that of $\mathrm{mx}-$ illary palpus; relative lengths of segments 2 to $3 \approx 1: 1.8$. $\mathrm{WP} / \mathrm{LP}=1.8-2.1 . \mathrm{LE} / \mathrm{WE}=1.3-1.4 . \mathrm{WP} / \mathrm{WE}=0.6-$ 0.7 .

Female. Female 3.6-5.0 mm long, 2.1-3.1 mm wide. Similar to males in color. $\mathrm{WP} / \mathrm{LP}=2.0-2.1 . \mathrm{LE} / \mathrm{WE}=$ 2.3-2.4. WP/WE $=0.6$.

Adult Diagnosis. This new subspecies is different from the nominate one by the shorter antennal rami and the emarginate apices of the maxillary and labial palpi.

Laval Diagnosis. Similar to the nominate subspecies, but differing by lacking the posterior sulci of the middorsal pronotal plate (Fig. 9C).

Etymology. Named after the distinguished native collector, Mr. M. Kimura.
Distribution. Japan (Okiwana island, Tarama island).

\section{Eubrianax insularis Nakane}

Eubrianax insularis Nakane, 1952: 41(CNJ; now in NSMT). - Satô 1965: 91.

Type Material. Types were examined: a couple mounted together, labeled "HOLOTYPE \ALLOTYPE $\backslash$ JAPAN Yakushima 10.IV.'12 $\backslash$ G.2.1.110 $\backslash 756$. $\$ Eubrianax insularis Nakane DET. T. NAKANE $\backslash 72$ 11." However, Nakane (1952) didn't indicate either specimen as holotype or paratype in the original paper. According to ICZN Art. 74.1, we formally designate the male as lectotype, and the female as paralectotype.

Male. Male $3.6 \mathrm{~mm}$ long, $2.3 \mathrm{~mm}$ wide. Coloration brown. Antennae (Fig. 15C) pectinate from segments 3 to 10 ; rami started from bases on segments 3 to 5 , from middles on segments 6 to 10; relative lengths of ramus to antennomere from segment 3 to $10 \approx 1.5: 2.2$ : 2.3: 2.2: 2.1: 2.0: 1.8: 1.3. Maxillar palpus (Fig. 15A) slender; terminal apically dilated, apex truncate; relative lengths of segment 2 to $4 \approx 1.2: 1: 1.3$. Labial palpus (Fig. 15A) small, $\approx 0.6$ times the length of maxillary palpus; terminal segment apically dilated, apex rounded; relativel lengths of segment 2 to $3 \approx 1$ : 1.4. $\mathrm{WP} / \mathrm{LP}=1.8 . \mathrm{LE} / \mathrm{WE}=1.2 . \mathrm{WP} / \mathrm{WE}=0.6$.

Aedeagus (Fig. 15B). Aedeagus -2.7 times as long as wide. Penis 0.8 times length of aedeagus, apex very slender, widened toward base, baso-lateral apophyses wide. Fibula wide, apex emarginate. Basal margins of ventral apophyses of parameres strongly serrate.

Variation. Consequent specimens differ from types by the blackish brown body, similar to Eubrianax manakikikuse and E. amamiensis.

Adult Diagnosis. Eubrianax insularis is similar to $E$. pellucidus, but differs by the wider fibula, the longer penis, and the blackish brown body.

Material Examined. JAPAN: Yaku Island: 1 male, Shiratani-rindo, 14-16-VII-97, Yoshitomi, NHMW;1 male, Yodogawa-path, 9-VII-94, Tsuyuki, NWU.

Distribution. Japan (Yaku-shima Island).

\section{Eubrianax serratus species group}

Adult Diagnosis. Differs from the other two groups by the male serrate antennae and the truncate apex of the prosternal process.

Larval Diagnosis. Differs from other two groups by having the posterior plates on the main plates of the abdominal segments 1 to 3 .

Pupal Diagnosis. Marginal extensions without micro-spined projections.

Included Species. Eubrianax serratus sp. nov.

\section{Eubrianax serratus sp. nov.} (Figs. 16 and 17)

Type Material. HOLOTYPE: male, TAIWAN: Kaohsiung, Changshan Rd. 20, 92 km, 20-XII-92-1-II- 
93, Lee, NHMW. PARATYPES: 16 males, 11 females, same data, NTUC, NHMW; 8 males, 1 female, $100 \mathrm{~km}$, 29-XII-92-2-II-93, Lee, NTUC; 4 males, 2 females, 108 km, 2-24-I-93, Lee, NTUC; Nantou: 5 males, 3 females, Luku, 13-22-I-93, Lee, NTUC.

Male. Male 4.2-4.4 mm long, 2.3-2.4 mm wide. Coloration blackish brown, but pronotum laterally yellowish brown and femora paler. Antenna (Fig. 16C) serrate from segments 3 to 10 ; segment 3 longest and less serrate than others; segments 4 to 10 similar in length. Maxillary palpus (Fig. 16A) short, apex rounded; relative lengths of segments 2 to $3 \approx 1.7$ : 1 : 1.7 . Labial palpus (Fig. 16A) $\approx 0.6$ times as long as maxillary palpus; terminal segment enlarged; relative length of segments 2 to $3 \approx 1: 1.1$. $\mathrm{LE} / \mathrm{WE}=1.4$. WP/LP $=$ 1.9-2.0. WP/WE $=0.6$.

Aedeagus (Fig. 16B). Aedeagus 2.5 times as long as wide. Penis 0.9 times the total length of genitalia; apically tapering from basal one-fifth; apex rounded. Parameres 0.8 times the length of tegmen; ventral apophyses short..

Female. Female 5.3-6.2 mm long, 3.5-4.1 mm wide. Similar to males in color, but pronotum yellowish brown with median longitudinal black band and abdomen yellowish brown. Antenna (Fig. 16D) filiform from segments 3 to 10 , segment 3 longest, segments 4 to 10 similar in length. Pronotum more transverse. Prosternal process wider. Abdomen bigger than elytra, apex exposed. LE/WE $=1.2-1.3 . \mathrm{WP} / \mathrm{LP}=2.7-3.0$. $\mathrm{WP} / \mathrm{WE}=0.6$.

Adult Diagnosis. This new species is characterized by the male serrate antennae and the truncate apex of the prosternal process..

Larval Diagnosis (Fig. 17). The posterior plates are present on abdominal segments 1 to 3 , not including pleurites.

Pupal Diagnosis. Opening of spiracles are restricted in lateral sides (Fig. 7C), similar to Eubrianax edwardsi. Number of opening is variable because of sexual dimorphism; $29-33$ in males $(n=5) ; 59-65$ in females $(n=5)$. Marginal extensions have no microspined projections.

Biology. Eubrianax serratus is sympatric with $E$. niger Lee \& Yang. However, the emergence of adults of the former precede the latter by 1 mo. Such differentiation is enough to cause preproductive isolation between both species because adults are short-lived.

Etymology. Serratus from Latin (serrate), indicating the serrate male antennae.

Distribution. Some larvae collected from Tainan County. Thus far, known from three counties in central and south Taiwan.

\section{Key to the Genera of the Eubrianacinae Based on Larvae}

1. Body form oblong; periocellar sulci conjoined apically (Fig. $5 \mathrm{~A}$ and B); mandibles thick and with apical teeth (Fig. $3 \mathrm{C}$ and D) . . . . . . 2

1'. Body form oval; periocellar sulci incomplete or absent (Fig. 4 A-C); mandibles flattened and without teeth (Fig. $3 \mathrm{~A}$ and B) . . . . . . 3 3
2. With crevices between abdominal terga 6 and 7 (Fig. 5A); teeth at sides of basal pieces of marginal peg setae reduced near bases (Fig. 6C); posterior plates on main areas of abdominal segments 1 to 3 (Fig. 5A) ... Jaechanax

$2^{\prime}$. Without crevices between abdominal terga 6 and 7 (Fig. 5B); teeth at sides of basal pieces of marginal peg setae developed well (Fig. $6 \mathrm{~B})$; posterior plates on abdominal segments 1 to 4 and pleurites on segment 5 (Fig. 5B) .

Mubrianax

3. Costal lines absent; mid-pronotal longitudinal sulci present (Fig. 4A); only one side of apical pieces of marginal peg setae with teeth (Fig. 6A) ................. Jinbrianax

3'. Costal lines present; mid-pronotal longitudinal sulci absent (Fig. 4 B and C); both sides of apical pieces of marginal peg setae with teeth (Fig. 6B) . . . . . . . . . . . . 4 4

4. With crevices between abdominal terga 6 and 7; dividing sulci of posterior plates on thoracic segments present (Fig. 4C); apical setae at apical pieces of marginal peg setae lanceolate.

Odontanax

$4^{\prime}$. Without crevices between abdominal terga 6 and 7; dividing sulci of posterior plates on thoracic segments absent (Fig. 4B) (except $E$. amamiensis); apical setae at apical pieces of marginal peg setae multifurcate (Lee et al. 1999c; Fig. 5) (except E. pellucidus) . . . . . .

Eubrianax

\section{Key to the Genera of the Eubrianacinae Based on Pupae}

1. Unexposed pupae; only spiracles sclerotized; all openings of spiracles concentrated at outward margins (Figs. $7 \mathrm{D}$ and E) . . . . . . . . . . 2

$1^{\prime}$. Exposed pupae; last three abdominal terga sclerotized; at least some openings extending inside spiracles (Fig. 7 A-C) . . . . . . . . . 3

2. Outward margin of each spiracle with one row of openings, with one process near base (Fig. 7E).

Jaechanax

$2^{\prime}$. Outward margin of each spiracle with two rows of openings, without processes near base (Fig. 7D) ................. Odontanax

3. Whole spiracles raised; openings confined to vermiculations and surrounding perimeter (Fig. 7A); posterior margins of abdominal terga with setae (Lee et al. 1999c; Fig. 15) . . Jinbrianax

$3^{\prime}$. Spiracles flat; at least one row of openings confined to outward margins of spiracles (Fig. 7 $\mathrm{B}$ and $\mathrm{C})$; posterior margins of abdominal terga without setae . . . . . . . . . . . 4

4. Openings numerous and tiny, densely and randomly distributed on spiracles, outward margins not emarginate behind processes (Fig. 7B); marginal extensions further divided, tightly connected (Lee et al. 1999b; Fig. 4) . ................. Mubrianax 
$4^{\prime}$. Openings fewer and large, sparsely scattered on spiracles, outward margins emarginate behind processes (Fig. 7C); marginal extension with pointed processes (Lee et al. 1999c; Fig. 14) Eubrianax

\section{Key to the Genera of the Eubriancinae Based on Adults}

1. Without pulvilli at tarsal claws . . . . . . . 2

1 '. With pulvilli at tarsal claws ......... 4

2. Formula of tibial spurs 2-2-2; elytra shining metallically. ........... Jinbrianax

2'. Formula of tibial spurs 2-1-1; elytra not shining.

3. Tarsal claws with notches near bases (Fig. 1B); mesal margins of parameres smooth (Fig. 2C); antennal rami originating apically on segments 4 to 7 ; prosternal process short and acute. . . ................ Mubrianax

3'. Tarsal claws wthout notches near bases (Fig. 1A); with processes at mesal margins of each paramere (Fig. 2B); antennal rami originating basally or medially on segments 4 to 7 (except Odontanax maculicollis); prosternal process long and dilated . . . . . . . . . Odontanax

4. Pulvilli membranous; tarsal claws long and slightly curved (Fig. 1A); apices of parameres without rounded sclerites covered (Fig. 2D).

................ Jaechanax

4'. Pulvilli well developed and pigmented; tarsal claws short and moderately or strongly curved (Fig. $4 \mathrm{C}$ and D); apices of parameres with rounded sclerites covered (e.g., Figs. $2 \mathrm{E}$ and 10B) .............. (Eubrianax) 5

5. Male antennae serrate (Fig. 16C); apex of prosternal process truncate . . . . serratus group

5'. Male antennae pectinate (e.g., Fig. 10C); apex of prosternal process acute or dilated . . . . . 6

6. Male antennal rami originating from bases or middles on segments 5 to 7 (Fig. 10C, 12D, 13 $\mathrm{D}$ and $\mathrm{E}, 15 \mathrm{C}) \ldots . . . .$. pellucidus group

$6^{\prime}$. Male antennal rami originating from apices on segments 5 to 10 (Lee et al. 1999a; Figs. 7 and 11) .................. . . . .

7. Apex of posternal process dilated; tarsal claws strongly curved (Fig. 1D) . . . . . . . . group

$7^{\prime}$. Apex of posternal process acute; tarsal claws moderately curved (Fig. 1C) . . . . . . . . . ............. ramicollis group

\section{Checklist of the Species and their Distributions of Eubrianacinae}

Jäch (1984) listed 38 species and three subspecies in Eubrianax, excluding a fossil species E. vandeli Bertrand and Laurentiaux, 1963. Of these E. flabellicornis Pic, 1922 was designated as the type species of $\mathbf{M i}$ croeubrianax by Pic (1954). This genus was synonymized with Psephenoides in another subfamily Psephenoidinae (Lee and Jäch 1995). And E. luteosignatus Pic, 1947 from Chile should be transferred to subfam- ily Eubriinae. Three species, E. palawanus Pic (1926), E. albomaculatus Pic (1926), and E. longipennis Pic (1915) are not in this list. Eubrianax longipennis is excluded from the present checklist because it is possible that no members of the subfamily are distributed in South America, although the type specimens of $E$. longipennis have not been found in the Paris museum.

Although we are making attempts to revise and redescribe all species of this subfamily, most African species and E. albomaculatus are not covered because only type specimens are available. They are temporarily treated as species incertae sedis.

\section{Genus Jinbrianax Lee, Satô, and Yang 1999c}

1. Jinbrianax apicalis (Pic 1913) Indonesia

2. Jinbrianax incompositus Lee, Satô, and Yang 1999c Nepal

3. Jinbrianax jaechi Lee, Satô, and Yang 1999c E. Malaysia

4. Jinbrianax javanus (Pic 1913) Indonesia

5. Jinbrianax metallicus (Pic 1922) Vietnam, Thailand, W. Malaysia = Eubrianax binhana Pic 1928

6. Jinbrianax rotundatus Lee, Satô, and Yang 1999c Nepal

7. Jinbrianax schillhammeri Lee, Satô, and Yang 1999c Laos

8. Jinbrianax semiaenescens (Pic 1921) Philippines, E. Malaysia

9. Jinbrianax tenuis Lee, Satô, and Yang 1999c China

Genus Odontanax Lee, Satô, and Yang 2000a

10. Odontanax ceylonicus (Jäch 1982) Sri Lanka

11. Odontanax chinensis Lee, Satô, and Yang 2000a China

12. Odontanax dohertyi (Pic 1915) E. Malaysia, Indonesia $=$ Eubrianax dohertyi variety angustatus Pic 1930 .

13. Odontanax dudgeoni Lee, Satô, and Yang 2000a China

14. Odontanax flinti Lee, Satô, and Yang 2000a Sri Lanka

15. Odontanax laosensis (Pic 1923) Laos, Vietnam, India = Eubrianax tonkineus Pic 1935

16. Odontanax lioneli (Jäch 1982) Sri Lanka

17. Odontanax maculicollis (Fairmaire 1888) Vietnam, Laos, Thailand

18. Odontanax minimus (Pic 1913) E. Malaysia, Philippines

19. Odontanax obscuripes (Pic 1914a) India

20. Odontanax palawanus (Pic 1926) Philippines

21. Odontanax thai Lee, Satô, and Yang 2000a Thailand

\section{Genus Mubrianax Lee, Satô, and Yang 1999b}

22. Mubrianax atripennis (Pic 1931) Cameroon

23. Mubrianax basipennis (Pic 1913) Indonesia, Philippines = Eubrianax bicolor Pic 1955a.

24. Mubrianax robustior (Pic 1928) E. Malaysia Philippines 
Genus Jaechanax Lee, Satô, and Yang 2000b

25. Jaechanax dentatus Lee, Satô, and Yang 2000b Indonesia

26. Jaechanax elongatus Lee, Satô, and Yang 2000b Philippines

27. Jaechanax illiesi (Satô 1983) Philippines

28. Jaechanax insignis (Fairmaire 1904) Vietnam, Laos, Myanmar

29. Jaechanax major (Pic 1913) Thailand, Malaysia, Indonesia, Philippines = Eubrianax limbatithorax Pic 1923.

Genus Eubrianax Kiesenwetter $1874=$ Placonycha

Horn 1880 = Heibrianax Lee, Satô, and Yang 1999a syn. $\mathrm{n}$.

\section{Ramicornis Species Group}

30. Eubrianax edwardsii (LeConte 1874) United States

31. Eubrianax ihai Chûjô and Satô 1970 Japan

32. Eubrianax loochooensis Nakane 1952 Japan

33. Eubrianax niger Lee and Yang 1990 Taiwan = Eubrianax alishanensis Lee and Yang 1990

34. Eubrianax nobuoi Satô 1965 Japan

35. Eubrianax ramicornis Kiesenwetter 1874 Japan, Korea $=$ Eubrianax ramicornis brunneicornis $\mathrm{Na}$ kane 1952

36. Eubrianax meridianus Lee, Satô, and Yang 1999a Taiwan

37. Eubrianax tarokoensis Lee and Yang 1990 Taiwan = Eubrianax flavus Lee and Yang 1990.

\section{Granicollis Species Group}

38. Eubrianax granicollis Lewis 1895 stat. rev. Japan

39. Eubrianax maai (Lee, Satô \& Yang 1999a) com. n. from Heibrinax China

40. Eubrianax sichuanus (Lee, Satô, and Yang 1999a) com. n. from Heibrinax China

41. Eubrianax secretus (Lee, Satô, and Yang 1999a) com. n. from Heibrinax Taiwan, China

\section{Pellucidus Species Group}

42. Eubrianax manakikikuse Satô 1964 Japan, Taiwan = Eubrianax wulaiensis Lee and Yang, 1990 syn. $\mathrm{n}$.

43. Eubrianax pellucidus Lewis 1895 Japan, China

44. Eubrianax amamiensis Satô 1965 stat. n. Japan = Eubrianax amamiensis kimurai ssp. n. Japan.

45. Eubrianax insularis Nakane 1952 Japan

\section{Serratus Species Group}

46. Eubrianax serratus sp. n. Taiwan

\section{Species Incertae Sedis}

47. Eubrianax africanus Pic 1914b Angola

48. Eubrianax albomaculatus Pic 1926 China

49. Eubrianax brevis Pic 1955b Urundi
50. Eubrianax invittatus Pic 1951 Congo

51. Eubrianax mirei Bertrand \& Villiers 1970 Cameroon

52. Eubrianax scotti Pic 1953 Ethiopia

53. Eubrianax vittaticollis Pic 1934 Congo

\section{Acknowledgments}

We deeply thank J. Wenzel and W. D. Shepard for reading the manuscript. We thank G. A. Samuelson, M. A. Jäch, and the late T. Nakane for the loan of specimens. This research is supported by National Science Council NSC 89-2313-B$002-028$.

\section{References Cited}

Arnett, Jr., R. H., G. A. Samuelson, and G. M. Nishida. 1993. The insect and spider collections of the world. Sandhill Crane Press, Gainesville, FL.

Bertrand, H., and D. Laurentiaux. 1963. Une Larve (Psephenoïde) du Genre Eubrianax Kiesenw. (Coléoptères Eubrianacidae) dans l'Éocène Lacustre de l'Aude. Bull. Soc. His. Nat. Toulouse 98: 232-241.

Bertrand, H., and A. Villiers. 1970. Coléoptères Eubriidae Récoltés au Cameroun par Ph. Bruneau de Miré. Bull. I. F. A. N. 32: 442- 448 .

Blackwelder, R. E. 1930. The larva of Eubrianax edwardsii (LeC.) (Coleoptera: Psephenidae). Pan-Pac. Entomol. 6: $139-141$.

Chûjô, M., and M. Satô. 1970. Coleoptera of the Loo-Choo Archipelago (II): 12. Family Psephenidae; 13:Family Ptilodactylidae;14. Family Chelonariidae. Mem. Fac. Educ. Kagawa Univ., (2), 192: 14-16.

Fairmaire, M. L. 1888. Descriptions de Col 233 opt 232 res de 1146 Indo-Chine. Ann. Soc. Entomol. Fr.6: 333-378.

Fairmaire, M. L. 1904. Descriptions de Lamellicornes Indochinois nouveaux ou peu connus. Mission Pavie Indochine 1879-1895: 3: 86-90.

Farris, J. S. 1988. Hennig86, version 1.5. Published by the author, Port Jefferson, NY.

Gose, K. 1957. On three larvae of the genus Eubrianax. Bull. Kansai Nat. Sci. Soc. 10: 20-23 (in Japanese).

Hinton, H. E. 1955. On the respiratory adaptations, biology, and taxonomy of the Psephenidae, with notes on some related families (Coleoptera). Proc. R. Entomol. Soc. Lond. 125: 543-68.

Hinton, H. E. 1966. Respiratory adaptations of the pupae of beetles of the family Psephenidae. Philos. Trans. R. Soc. Lond. (B) 37: 211-245.

Horn, G. H. 1880. Synopsis of the Dascyllidae of the United Sates. Trans. Am. Entomol. Soc. 8: 76-114.

Jäch, M. 1982. Neue Dryopoidea und Hydraenidae aus Ceylon, Nepal, Neu Guinea und der Türkei (Col.). Koleopt. Rdsch. 56: 103-114.

Jäch, M. 1984. Die Koleopterenfauna der Bergbäche von Südwest-Ceylon. Arch. Hydrobiol. Suppl. 69: 228-332.

Kiesenwetter, H. 1874. Die malacodermen Japans nach dem ergenisse der sammlungen des Herrn G. Lewis während der Jahre 1869-1871. Berl. Entomol. Z. 18: 241-288.

LeConte, J. L. 1874. Descriptions of new Coleoptera cheifly from the Pacific slope of North America. Trans. Am. Entomol. Soc. 5: 43-72.

Lee, C.-F., and M. A. Jäch. 1995. Psephenidae: 1. Check list of the Psephenidae of China (Coleoptera), pp. 349-354. In M. A. Jäch and L. Ji [eds.], Water beetles of China. Zoologisch-Botanische Gesellschaft in Österreich and Wiener Coleopterologenverein, Wien. 
Lee, C.-F., and P.-S. Yang. 1990. Five new species of the genus Eubrianax from Taiwan (Coleoptera: Psephenidae). J. Taiwan Mus. 43: 79-88.

Lee, C.-F., M. Satô, and P.-S. Yang. 1999a. Revision of Eubrianacinae (Coleoptera, Psephenidae) I. Eubrianax Kiesenwetter and Heibrianax gen. n. Jpn. J. Syst. Entomol. 5: 9-25.

Lee, C.-F., M. Satô, and P.-S. Yang. 1999b. A revision of Eubrianacinae (Coleoptera, Psephenidae) II. Mubrianax gen. nov. Elytra 27: 429-438.

Lee, C.-F., M. Satô, and P.-S. Yang. 1999c. A revision of Eubrianacinae (Coleoptera, Psephenidae) III. Jinbrianax gen. nov. Entomol. Rev. Jpn. 54: 169-187.

Lee, C.-F., M. Satô, and P.-S. Yang. 2000a. A revision of Eubrianacinae (Coleoptera, Psephenidae) IV. Odontanax gen. nov. Jpn. J. Syst. Entomol. 6: 151-170.

Lee, C.-F., M. Satô, and P.-S. Yang. 2000b. A revision of Eubrianacinae (Coleoptera, Psephenidae) V. Jaechanax gen. nov. Elytra 28: 119-129.

Lee, C.-F., P.-S. Yang, and H. P. Brown. 1990. Notes on the genus Mataeopsephus (Coleoptera: Psephenidae) in Taiwan with description of a new species. J. Taiwan Mus. 43: 73-78.

Lewis, G. 1895. On the Dascillidae and Malacorderm Coleoptera of Japan. Ann. Mag. Nat. Hist. 6: 98-122.

Nakane, T. 1948. On the Japanese Dascillidae (Coleoptera). Bull. Takarazuka Insect 45: 1-16 (in Japanese).

Nakane, T. 1952. New or little known Coleoptera from Japan and its adjacent regions. 7. Dascillidae. Sci. Rep. Saikyo Univ. (Nat. Liv. Sci.) 1: 35-41.

Nixon, K. C. 1992. Clados, version 1.2. Published by the author, Ithaca, NY.

Pic, M. 1913. Diagnoses de Dascillides et Cyphonides nouveau. Échange 19: 171-173.

Pic, M. 1914a. Noveaux Coléoptères de diverses familles. Mel. Exot. Entomol. 10: 7-20.

Pic, M. 1914b. Dascillidae, Helodidae, Scraptiidae et Salpingidae, in: Voyage de Ch. Alluaud et R. Jeannel en Afrique Orientale (1911-1912). Result. Sci. Mem. Coleoptera 9: 299-326.

Pic, M. 1915. Descriptions agrégées diverses. Mel. Exot. Entomol. 12: 3-20.

Pic, M. 1921. Diagnoses de Coléoptères exotiques. Echange 37: 15-16.
Pic, M. 1922. Nouveautés diverses. Mel. Exot. Entomol. 37: $1-32$

Pic, M. 1923. Nouveautés diverses. Mel. Exot. Entomol. 40: 3-32.

Pic, M. 1926. Nouveautés diverses. Mel. Exot. Entomol. 46: $1-32$.

Pic, M. 1928. Coléoptères exotiques en partie nouveaux. Echange 44: 7-8

Pic, M. 1930. Dr. E. Mjöberg's Zoological Collections from Sumatra. 10 Dascilidae et Malacodermata. Ark. Zool. 21A: $1-6$

Pic, M. 1931. Nouveautés diverses. Mel. Exot. Entomol. 57: $1-36$.

Pic, M. 1934. XXXIII.- Nouveaux Coléoptères d'Afrique. Ann. Mag. Nat. Hist. 10: 386-392.

Pic, M. 1935. Coléoptères exotiques en partie nouveaux. Echange 51: 15-16.

Pic, M. 1947. Diversit 233 s Entomologiques. Les Imprimeries Réunies, Moulins 1: 1-16.

Pic, M. 1951. Un Eubrianax (Ksw.) nouveau du Congo. Rev. Zool. Bot. Afr. 44: 156.

Pic, M. 1953. Expedition to the Gughé Highlands (Southern Ethiopia), 1948-49: Coleoptera, Dascillidae: Une nouvelle espèce du genre Eubrianax. J. Linn. Soc. Lond. 42: 293-294.

Pic, M. 1954. Coléoptères nouveaux de Chine. Bull. Soc. Entomol. Mulhouse 1954: 61-64.

Pic, M. 1955a. Nouveaux Coléoptères de la collection Oberthur (1). Rev. Fr. Entomol. 22: 228-236.

Pic, M. 1955b. Contributions a l'étude de la faune entomologique du Ruande-Urundi (Mission P. Basilewsky 1953):Anna. Mus. R. Congo Bel. Tervuren (Ser.8) Sci. Zool. 36: 125-135.

Satô, M. 1964. Descriptions of new Dryopoid-beetles from the Ryukyus. Bull. Jpn. Entomol. Acad. 1: 31-37.

Satô, M. 1965. Dryopoidea of the Ryukyu Archipelago, I. J. Nagoya Wom. Coll. 11: 76-94.

Satô, M. 1983. A new Eubrianax species (Col., Psephenidae) from the Philippines. Aqua. Insects 5: 65-58.

Watrous, L. E., and Q. D. Wheeler. 1981. The outgroup comparison method of character analysis. Syst. Zool. 30: $1-11$.

Received for publication 5 October 2000; accepted 9 January 2001.

Appendix 1. Data matrix for phylogenetic analysis

\begin{tabular}{llllllllllllllllllllllllllll}
\hline \hline \multirow{2}{*}{ Character } & 0 & 0 & 0 & 0 & 0 & 0 & 0 & 0 & 0 & 1 & 1 & 1 & 1 & 1 & 1 & 1 & 1 & 1 & 1 & 2 & 2 \\
Species & 1 & 2 & 3 & 4 & 5 & 6 & 7 & 8 & 9 & 0 & 1 & 2 & 3 & 4 & 5 & 6 & 7 & 8 & 9 & 0 & 1 \\
\hline Mataeopsephus & 0 & 0 & 0 & 0 & 0 & 0 & 0 & 0 & 0 & 0 & 0 & 0 & 0 & 0 & 0 & 0 & 0 & 0 & 0 & 0 & 0 \\
Jinbrianax & 1 & 1 & 0 & 0 & 0 & 1 & 0 & 0 & 0 & 2 & 0 & 0 & 0 & 0 & 0 & 1 & 1 & 0 & 0 & 0 & 0 \\
Odontanax & $?$ & 0 & 1 & 0 & 0 & 1 & 0 & 0 & 0 & 0 & 1 & 1 & 1 & 1 & 0 & 2 & 1 & 1 & 1 & 0 & 1 \\
Mubrianax & 1 & $?$ & 1 & 0 & 0 & 0 & 0 & 0 & 1 & 1 & 1 & 1 & 1 & 0 & 1 & 2 & 1 & 1 & 2 & 1 & 1 \\
Jaechanax & 2 & 1 & 1 & 1 & 0 & 0 & 1 & 0 & 1 & 1 & 1 & 1 & 2 & 1 & 1 & 2 & 1 & 1 & 1 & 2 & 1 \\
Heibrianax & 1 & 0 & 1 & 2 & 1 & 0 & 1 & 1 & 0 & 2 & 1 & 0 & 0 & 0 & 0 & 2 & 2 & 1 & 2 & 2 & 1 \\
Eubrianax tarokoensis & 1 & 1 & 1 & 2 & 1 & 0 & 1 & 1 & 0 & 2 & 1 & 0 & 0 & 1 & 0 & 2 & 2 & 1 & 2 & 2 & 1 \\
Eubrianax pellucidus & 2 & 1 & 1 & 2 & 1 & 0 & 1 & 1 & 0 & 1 & 1 & 0 & 0 & 0 & 0 & 2 & 1 & 1 & 2 & 2 & 1 \\
Eubrianax amaniensis & 2 & 1 & 1 & 2 & 1 & 0 & 1 & 1 & 0 & 1 & 1 & 1 & 0 & 0 & 0 & 2 & 2 & 1 & 2 & 2 & 1 \\
Eubrianax manakikikuse & 2 & 1 & 1 & 2 & 1 & 0 & 1 & 1 & 0 & 0 & 1 & 0 & 1 & 1 & 0 & 2 & 2 & 1 & 2 & 2 & 1 \\
Eubrianax serratus & 0 & $?$ & 1 & 2 & 1 & 0 & 1 & 1 & 0 & 2 & 1 & 0 & 2 & 0 & 0 & 2 & 2 & 1 & 2 & 2 & 1 \\
\hline
\end{tabular}

